\title{
Sylfjellet: a new outcrop of the Paleogene Van Mijenfjorden Group in Svalbard
}

\author{
Malte Michel Jochmann ${ }^{1}$ (1) $\cdot$ Lars Eivind Augland ${ }^{2} \cdot$ Olaf Lenz $^{3} \cdot$ Gerd Bieg $^{4} \cdot$ Turid Haugen $^{5}$. \\ Sten Andreas Grundvåg ${ }^{6} \cdot$ Mads E. Jelby ${ }^{7}$ · Ivar Midtkandal ${ }^{8}\left(\mathbb{D} \cdot\right.$ Martina Dolezych $^{3} \cdot$ Hanna Rósa Hjálmarsdóttir $^{1,9}$
}

Received: 9 August 2019 / Accepted: 22 November 2019 / Published online: 5 December 2019

(c) The Author(s) 2019

\begin{abstract}
A hitherto unrecognized Paleogene outcrop has been discovered at Sylfjellet, a mountain located at the northern side of Isfjorden, Svalbard. The strata, which cover an area of $0.8 \mathrm{~km}^{2}$, have until now been assigned to the Lower Cretaceous succession of the Adventdalen Group. In this study, the Sylfjellet site was studied in detail to provide an updated structural and sedimentological description of strata and lithostratigraphy. The age and burial history of the investigated succession were constrained by absolute (U/PB) and relative dating methods in addition to vitrinite reflectance analyses of coal seams. The results show a Paleogene age of the deposits, which is supported by the occurrence of an angiosperm pollen grain, plant macrofossils, and a tephra layer of early Selandian age (61.53 Ma). The $250 \mathrm{~m}$-thick succession of Sylfjellet is assigned to the Firkanten, Basilika and Grumantbyen formations. This succession unconformably overlies the Lower Cretaceous Helvetiafjellet Formation. Sylfjellet is incorporated into the West Spitsbergen Fold-and-Thrust Belt and interpreted to be a fourth structural outlier of the Van Mijenfjorden Group. Vitrinite reflectance data indicate that at least $2000 \mathrm{~m}$ overburden has been eroded above the Sylfjellet coal seams, and that maximum burial of the strata predates folding and thrusting in the area.
\end{abstract}

Keywords Stratigraphy · West Spitsbergen Fold-and-Thrust Belt · Absolute dating · Central Tertiary Basin · Eurekan orogeny $\cdot$ Vitrinite reflectance

\section{Introduction}

The mountain Sylfjellet is incorporated into the West Spitsbergen Fold-and-Thrust Belt (WSFTB; [1]) on central to western Spitsbergen, the largest island of the Svalbard

Electronic supplementary material The online version of this article (https://doi.org/10.1007/s41063-019-00072-w) contains supplementary material, which is available to authorized users.

Malte Michel Jochmann

maltej@unis.no

1 Department of Arctic Geology, The University Centre in Svalbard (UNIS), P.O. Box 156, 9171 Longyearbyen, Norway

2 Centre for Earth Evolution and Dynamics (CEED), University of Oslo, P.O. Box 1028, Blindern, 0315 Oslo, Norway

3 Senckenberg Naturhistorische Sammlungen Dresden, Königsbrücker Landstraße 159, 01109 Dresden, Germany

4 Gisela Bieg Mikroskopische Untersuchungen, Hirschgraben 2, 45721 Haltern am See, Germany archipelago. The mountain forms a characteristic double peak with the highest peak Syltoppen at $680 \mathrm{~m}$ above sea level (masl), and lies within the panoramic view of Longyearbyen, the Norwegian main settlement of Svalbard (Fig. 1).

In one of the first geological maps of Spitsbergen, the topmost strata at Sylfjellet are assigned to the Jurassic [2]. All subsequently published geological maps assign the strata

5 Norges vassdrags-og energidirektorat (NVE), Region Nord, Kongensgate 52-54 Capitolgården, 8514 Narvik, Norway

6 Department of Geosciences, UiT-The Arctic University of Norway, P.O. Box 6050, Langnes, 9037 Troms $\varnothing$, Norway

7 Department of Geosciences and Natural Resource Management, University of Copenhagen, Øster Voldgade 10, 1350 Copenhagen K, Denmark

8 Department of Geosciences, University of Oslo, P.O. Box 1047, Blindern, 0316 Oslo, Norway

9 Natural History Museum, University of Oslo, P.O. Box 1172, Blindern, 0318 Oslo, Norway 


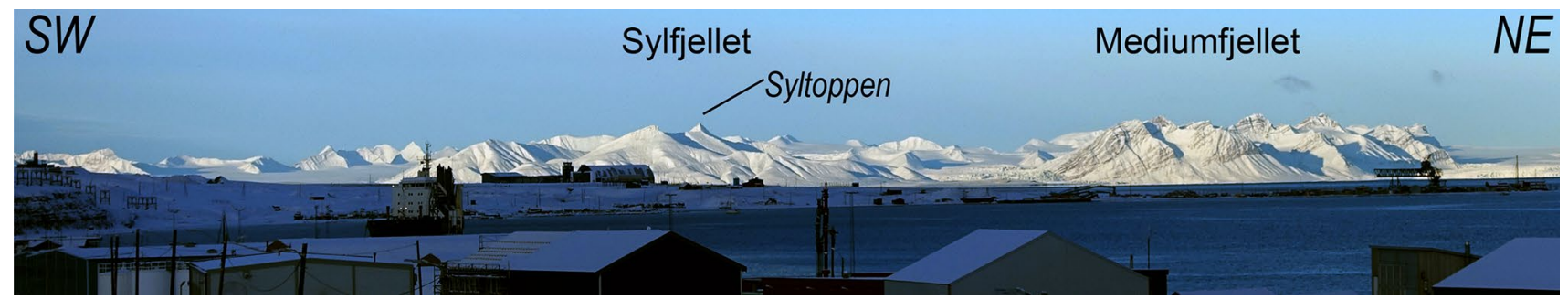

Fig. 1 The panoramic view from Longyearbyen toward the northern coast of Isfjorden with the prominent double peak of Sylfjellet. The mountain Mediumfjellet is known among geologists due to the well-exposed thrust tectonics

of the upper parts of Sylfjellet to the Lower Cretaceous Helvetiafjellet and Carolinefjellet formations of the Adventdalen Group (e.g., [3-9]) or simply the Helvetiafjellet Formation, as in the most recent official geological map (scale 1:100,000 [10], Fig. 2). Several publications on the area agree with this assignment (e.g., [11-14]). Consequently, Sylfjellet represents the northernmost known exposure of Lower Cretaceous strata on Spitsbergen.

In 2015, during fieldwork targeting the Lower Cretaceous strata, doubt arose concerning the age of this succession and initiated this study. A Paleogene age might indicate the presence of a hitherto unknown structural outlier of the Van Mijenfjorden Group and may therefore contribute to an updated reconstruction of the regional paleogeography, basin fill evolution and the much debated structural development and exhumation history of Svalbard and adjacent Paleogene basins (e.g., [1, 13, 15-25].

In this paper, the strata at Sylfjellet, here informally referred to as the Sylfjellet succession, are re-visited and new findings from recent fieldwork reported. The objective of this paper is to describe the structural and sedimentological character of the stratigraphic succession at Sylfjellet, with an overall aim at revising its age and lithostratigraphic affinity.

\section{Geological setting}

\section{Structural elements of the area}

The WSFTB (Fig. 2, synonymous to "Tertiary fold-andthrust belt of Spitsbergen" in [5]) developed as part of the Eurekan Orogeny, thus recording the collision between the Eurasian and the Greenland Plate prior to and/or during the opening of the North Atlantic along the De Geer Fracture Zone [25]. The WSFTB shows both thin- and thick-skinned thrust deformation [5].

In Oscar II Land, Berg et al. [26] subdivided the WSFTB into three zones from west to east: (1) a basement-involved fold-and-thrust complex; (2) a central zone with thinskinned fold-and-thrust tectonics, an underlying decollement zone mainly in Permian evaporites and blind fault dominated; (3) an eastern zone representing the thrust front with emerging thrusts and reactivated older fault systems in the east, showing monoclinal structures (the Billefjorden and Lomfjorden fault zones). Sylfjellet is situated in the central zone, just southwest of the thrust ramp of Mediumfjellet (Figs. 1 and 2). From north to south, the WSFTB can be subdivided into two different segments: In the northern segment, the main fold-and-thrust complex reaches a maximum width of $30 \mathrm{~km}$ and no foreland basin sediments are found east of it. In the southern segment, the intensely folded part is only $10-15 \mathrm{~km}$ wide and foreland basin sediments of the Van Mijenfjorden Group are preserved in the Central Tertiary Basin (CTB) ([12, 27, 28], Fig. 2). A tear or transfer fault system, the Isfjorden-Ymerbukta Fault Zone (IYFZ) $[13,26]$, divides the northern segment of the WSFTB from the southern segment $[25,29]$. It can be traced along the northern coast of Isfjorden (Fig. 2). The fault zone is rooted in the basement, traceable for $50 \mathrm{~km}$, less than $500 \mathrm{~m}$ wide and it has a vertical throw of minimum $650 \mathrm{~m}$ and a horizontal dextral component of $5-10 \mathrm{~km}$. [13]. The timing of the IYFZ is a subject of debate: Braathen et al. [13] suggest one or multiple phases during early Paleocene to middle Eocene times, while Harland and Horsfield [30] argue for movement occurring in the late Tertiary (i.e., Neogene) to Pleistocene with displacement of less than $5 \mathrm{~km}$. The IYFZ corresponds to the Isfjorden Fault in Harland and Horsfield [30], the Ymerbukta Fault in Ohta et al. [31], the Syltoppen Fault in Kellogg [12] and the Ymerbukta transfer (tear) fault in Piepjohn et al. [25]. This study refers to the CTB as the structural synclinorium, whereas the Paleogene infill in the CTB is referred to as the Van Mijenfjorden Group.

\section{Lithostratigraphy of the Van Mijenfjorden Group}

The main part of the Paleogene Van Mijenfjorden Group is preserved in the CTB where it consists of Paleocene to Eocene (Oligocene?) ([9] and ref. herein) strata with Erdmannflya as the northernmost outcrop (Fig. 2a).

The up to $1.9 \mathrm{~km}$-thick group contains seven formations within the CTB, and the Ny-Ålesund Subgroup outside the CTB [9] (Fig. 2b, c). 
There are presently three known structural outliers to the CTB which are defined as part of the Van Mijenfjorden Group: (1) the Ny-Ålesund Subgroup at Kongsfjorden (Fig. 2), which is incorporated into heavily folded and thrust strata in the northwest, (2) the deposits at Sommerfeldtbukta in the very southern part of Spitsbergen, preserved in the Øyrlandet Graben [32-34] (i.e., Øyrlandet Basin in [7]) and (3) the folded and thrust outcrop on the western side of Grønfjorden [25, 35]. According to the lithostratigraphic lexicon of Svalbard [9], the outliers at Ny-Ålesund and Øyrlandet are correlative to the lower part of the Van Mijenfjorden Group within the CTB. This is not supported by all studies, e.g., Livšic [14] or Cepek and Krutzsch [36].

Across the CTB, the Van Mijenfjorden Group unconformably overlies the Lower Cretaceous strata, recording Late Cretaceous to early Paleocene uplift and erosion. In the NyAllesund area, the hiatus spans from Permian/earliest Triassic to Paleocene [12,37], indicating increasing uplift and erosion toward the NW [32, 38-40].

The lower part of the group comprises the Firkanten, Basilika and Grumantbyen formations and the Marstranderbreen Member of the Frysiaodden Formation (Fig. 2). It correlates with the Kongsfjorden and Brøggerbreen formations of the Ny-Ålesund Subgroup [9]. It is debated if the basin initially developed from strike slip movement [28], extension/transtension [7, 27, 41] or transpression/compression $[22,23]$. The sediment source was located toward the $\mathrm{N}$ and $\mathrm{E}[42,43]$. The depositional age of the lower part of the group is latest Danian to Thanetian in the northern part of the CTB [23, 44].

The upper part of the Van Mijenfjorden Group (i.e., the Hollendardalen, upper Frysiaodden, Battfjellet and Aspelintoppen formations, Fig. 2) were deposited in a foreland basin setting [45]. Two different models for the contractional regime are suggested: Dextral transpression with decoupling of strain [46-48], or a polyphase development with orthogonal compression and transpression [1,25]. The source area was mainly the evolving Eurekan Fold-and-Thrust Belt in the west [42] and deposition started in the latest Thanetian [27, 42-44]. The Paleocene-Eocene boundary has been well defined in the lower Frysiaodden Formation [44], but the age of the youngest preserved parts of the Aspelintoppen Formation is debated with middle Eocene to Oligocene as suggestions [14, 33, 36, 49]. The Van Mijenfjorden Group strata are well lithified with vitrinite reflectance between 0.4 and $0.7 \%$ in the Aspelintoppen Formation [50-52]. Consequently, $>1 \mathrm{~km}$ of strata must have been present above the Van Mijenfjorden Group [50-53].

Two other Paleogene successions are described in western Svalbard: the Eocene/Oligocene (?) Calypsostranda Group at Bellsund and the Eocene/Oligocene (?) Buchananisen Group located in the Forlandsundet Graben [7, 9] (Fig. 2).

\section{Stratigraphic development of the Firkanten Formation}

The Firkanten Formation reflects the start of Paleocene sedimentation on Spitsbergen and consists of three members (Fig. 2b). The lower continental to paralic Todalen Member is known to contain commercial volumes of coal, and $90 \%$ of the coal produced in Svalbard originates from this unit [54]. The member displays an overall transgressive trend throughout the basin. Different paleogeographic interpretations for the Todalen Member have been suggested: Steel et al. [55] proposed three half-graben-related sub-basins which progressively developed toward the north. Nagy's [56] paleogeographic interpretation of the Todalen Member was based on foraminiferal facies and sequence stratigraphic analysis and shows a concurrent coastline stretching NNW-SSE with an open sea toward the west. Lüthje [57], on the other hand, documented significant onlap toward the north, with the Todalen Member deposits younging from the Svea-area toward Longyearbyen.

The upper part of the Firkanten Formation is characterized by the cliff-forming and sandstone-dominated Endalen Member, representing deltaic and shoreface deposits. Its lateral equivalent in the distal parts of the basin is pro-deltaic to shelf deposits of the Kolthoffberget Member, preserved in the western and southern parts of the CTB.

\section{Methods}

\section{Fieldwork and mapping}

Fieldwork was carried out on Sylfjellet during three field campaigns in 2015, 2016 and 2017. The steep and alpine area was mapped where accessible, and sedimentary sections were logged in concert with rock sampling for further analyses. Partly, logging was performed using rope belay. The outcropping strata were measured bed by bed, and rock type, texture, sedimentary structures, geometry as well as body and trace fossils were noted. Visual observations, photographs, and subsequently orthophotographs were used to map the geology of inaccessible areas.

\section{$\mathrm{U}-\mathrm{Pb}$ zircon dating}

A $28 \mathrm{~cm}$-thick bed of plastic, yellowish-grayish bentonite was sampled (sample OSL 16-2) from the base of the mapped succession (Fig. 3). The sampled material was packed in an airtight plastic sample bag for transport and further preparation. In the laboratory at the University of Oslo, the bentonite was washed and sieved before separation of heavy minerals through standard magnetic and heavy liquid techniques. Selected zircons were 

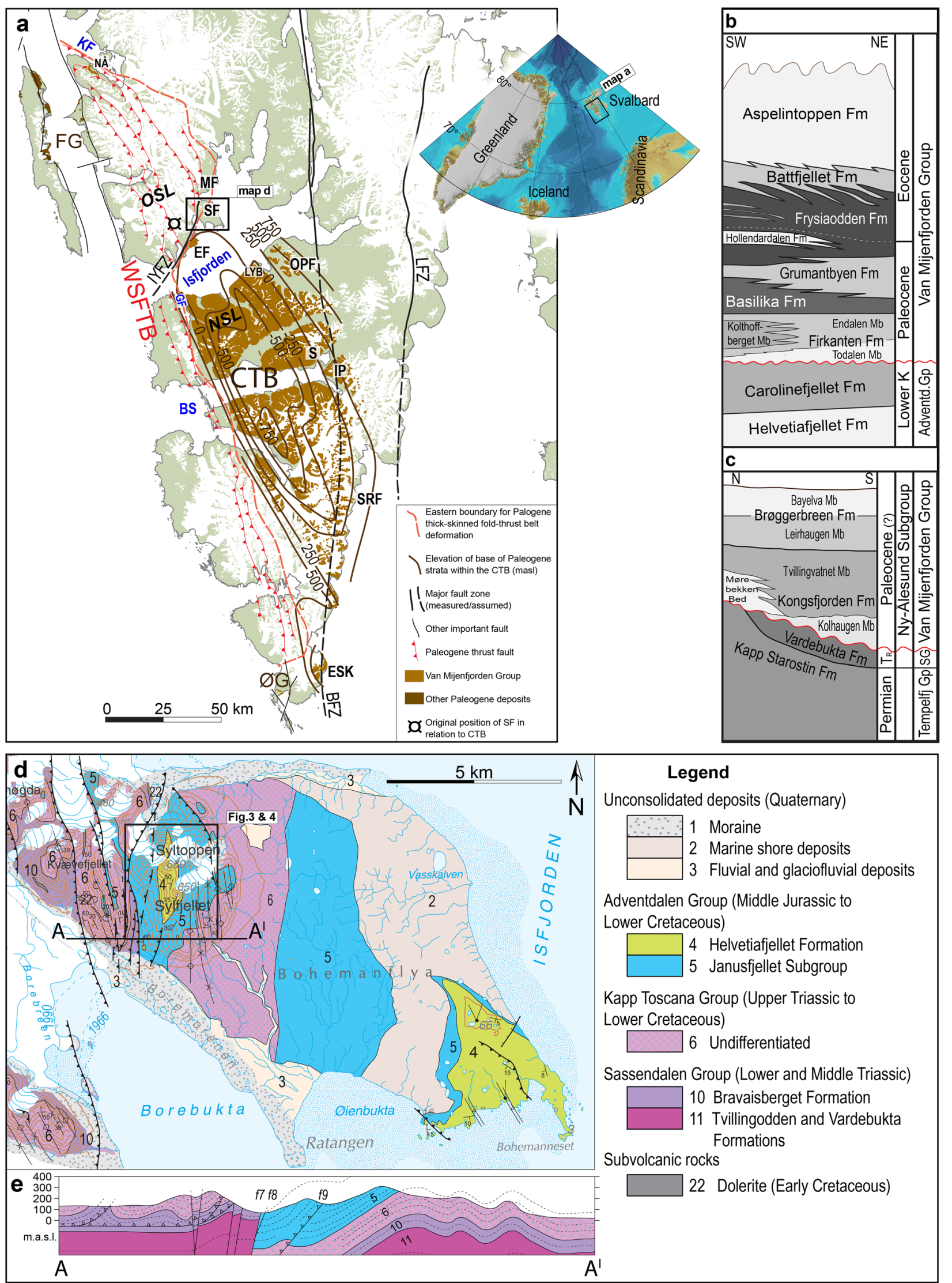

\section{Unconsolidated deposits (Quaternary) \\ $\therefore \because 1$ Moraine \\ 2 Marine shore deposits \\ 3 Fluvial and glaciofluvial deposits}

Adventdalen Group (Middle Jurassic to Lower Cretaceous)

\begin{tabular}{|l|ll}
\hline & 4 & Helvetiafjellet Formation \\
5 & Janusfjellet Subgroup
\end{tabular}

Kapp Toscana Group (Upper Triassic to Lower Cretaceous)

$$
6 \text { Undifferentiated }
$$

Sassendalen Group (Lower and Middle Triassic) \begin{tabular}{|l|l}
\hline & 10 Bravaisberget Formation \\
11 & Tvillingodden and Vardebukta
\end{tabular} Formations

Subvolcanic rocks

\section{\begin{tabular}{|l}
\hline \\
$\square$
\end{tabular} 2 Dolerite (Early Cretaceous)}


4Fig. 2 a Southern Spitsbergen with the most important structural elements and Paleogene strata as shown in existing maps. Paleogene troughs, basins and fold belts: $C T B$ Central Tertiary Basin, FG Forlandsundet Graben, WSFTB West Spitsbergen Fold-and-Thrust Belt, $\varnothing G \varnothing$ yrlandet Graben. Fault Zones: BFZ Billefjorden Fault Zone, IYFZ Isfjorden-Ymerbukta Fault Zone, LFZ Lomfjorden Fault Zone; Important localities (from $\mathrm{N}$ to $\mathrm{S}$ ): $N \AA \mathrm{Ny}$-Ålesund, $O S L$ Oscar II Land, $M F$ Mediumfjellet, $S F$ Sylfjellet, $E F$ Erdmannflya, $O P F$ Operafjellet, $L Y B$ Longyearbyen, GF Grønfjorden, NSL Nordenskiöld Land, $S$ Svea, $I P$ Ispallen, $B S$ Bellsund, $S R F$ Schönrockfjellet, ESK eastern Sørkappland. a restored position of the Sylfjellet succession as discussed in the text. Modified from [4] and [94], basemap (C) Norwegian Polar Institute [95]. Overview map from [96]. b The lithostratigraphy of the Van Mijenfjorden Group in the CTB. Adventd. Gp Adventdalen Group. Modified from [55]. c The lithostratigraphy of the Ny-Ålesund Subgroup, Van Mijenfjorden Group. Tempelf $G p$ Tempelfjorden Group, $S G$ Sassendalen Group, $T_{R}$ Triassic; After $[9,97]$. d The existing official geological map (original scale 1:100 000) of the Sylfjellet area. Slightly modified from [10]. e Redrawn geological cross section from Braathen [13] through the IYFZ crossing the southern slope of Sylfjellet. The major steep fault zone f 7/8, just west of Sylfjellet has a vertical displacement of $600 \mathrm{~m}$

annealed for c. $72 \mathrm{~h}$ at $900{ }^{\circ} \mathrm{C}$ and chemically abraded with $\mathrm{HF}(+\mathrm{HNO} 3)$ at $195{ }^{\circ} \mathrm{C}$ for $14 \mathrm{~h}$ [58, 59]. After optical inspection, euhedral high aspect ratio $(>1: 4)$ zircon grains were chosen for analyses, spiked with a mixed ${ }^{202} \mathrm{~Pb}-{ }^{205} \mathrm{~Pb}-{ }^{235} \mathrm{U}$ tracer, which has recently been calibrated to the EARTHTIME (ET) 100 Ma solution [60] (Oslo), and dissolved in HF (+HNO3) at c. $210^{\circ} \mathrm{C}$ for $>48 \mathrm{~h}$ in Teflon microcapsules and a Parr-type bomb. All dissolved grains subsequently went through column chemistry to separate $\mathrm{U}$ and $\mathrm{Pb}$ from potentially interfering and ionization-inhibiting elements [61]. Details of the general mass spectrometric techniques used are presented in a previous article ([62]; with upgraded laboratory parameters: $\mathrm{Pb}$ blank generally $<1 \mathrm{pg}$ with a composition of ${ }^{206} \mathrm{~Pb} /{ }^{204} \mathrm{~Pb}=18.12 \pm 0.30 ;{ }^{207} \mathrm{~Pb} /{ }^{204} \mathrm{~Pb}=15.30 \pm 0.18$; ${ }^{208} \mathrm{~Pb} /{ }^{204} \mathrm{~Pb}=36.67 \pm 0.34$; improved precision of fractionation on $\mathrm{U}$ and $\mathrm{Pb}$ fractionation parameters of $0.02 \%$ and $0.003 \% 1 \sigma$ for $\mathrm{U}$ and $\mathrm{Pb}$, respectively). Reduction of raw data was conducted using Tripoli [63], and analytical errors and corrections (including common $\mathrm{Pb}$, fractionation corrections and Th corrections, assuming $\mathrm{Th} / \mathrm{U}$ in the magma of 3 ) were incorporated and propagated in the Excel macro based on the algorithms published in Schmitz and Schoene [64]. Ages were calculated by the use of the ISOPLOT Excel macro of Ludwig [65] using the decay constants of Jaffey et al. [66], and are presented with $2 \sigma$ errors as $X / Y / Z$, where $X$ includes only the analytical errors, $Y$ includes the analytical errors and tracer calibration errors, and $Z$ includes the analytical, tracer calibration and decay constant errors. The $\mathrm{U}-\mathrm{Pb}$ data are presented in Online Resource 1.

\section{Biostratigraphy}

For palynology, two coal samples (OSL-16-4 and OSL-16-7; see Fig. 3) were processed following the standard procedures described by Kaiser and Ashraf [67]. The samples were treated with $40 \%$ hydrofluoric acid (HF) for silicate removal and potassium hydroxide $(\mathrm{KOH})$. After sieving over a 12- $\mu \mathrm{m}$ nylon mesh sieve the residues were slightly oxidized by applying $30 \%$ hydrogen peroxide $\left(\mathrm{H}_{2} \mathrm{O}_{2}\right)$ to remove flocculating organic matter and improve the transparency of possible existing palynomorphs. After a final sieving the residues were analyzed at $400 \times$ magnification. For macroscopic fossil analysis, several macroscopic plant fossils were collected or photographed in the field. For foraminifera, two samples were prepared for analysis, following the kerosene method of Nagy et al. [68]. This method was chosen because of the lithified nature of the sediments.

\section{Vitrinite reflectance}

A total of 25 samples, each between 200 and $1200 \mathrm{~g}$, were collected from three coal seams in the field. Samples were taken from roof to floor to avoid mixing of the brittle material. Sample intervals were pre-defined or naturally defined by lithological boundaries or partings in the coal seams. The coal was packed in aluminum foil and plastic or cotton bags for transport. Sample preparation was carried out in accordance with the methods outlined in ISO 7404-2 [69]. After air drying and grain size reduction to less than $1 \mathrm{~mm}$, a laboratory sample of 85-200 g was obtained by splitting. A representative proportion of this sample was embedded in epoxy resin and prepared as polished mount according to ISO 7404-2. The particulate mount was sectioned perpendicular to any density stratification that developed during resin curing.

A modified Leica DM 4000 M binocular incident light microscope was used for coal petrographic analysis. The microscope was fitted with $20 \times, 32 \times$ and $50 \times$ oil immersion objectives, $10 \times$ oculars with adjustable eyepieces, LED incident light illumination including white light and blue light (fluorescence-mode illumination), two digital cameras Basler Scout scA1390-17fm and -17fc color, and ecodrive microscope scanning stage with power supply unit and software Hilgers Diskus-Fossil, and a imaging system was included.

Random reflectance $\left(R_{\mathrm{r}}\right)$ measurements were carried out following the standard ISO 7404-5 [70]. A total of 100 points were measured on vitrinite to determine the random reflectance. All reflectance measurements were documented by micrographs. The operators are accredited for vitrinite random reflectance analysis, maceral analyses and coal blend petrographic analysis by the International Committee for Coal and Organic Petrology (ICCP). 
Fig. 3 Overview map (for extent see Fig. 2d) showing sample locations, mapped units and elements that were changed or modified from the official geological map [10]. Quaternary elements were mapped based on orthophotos

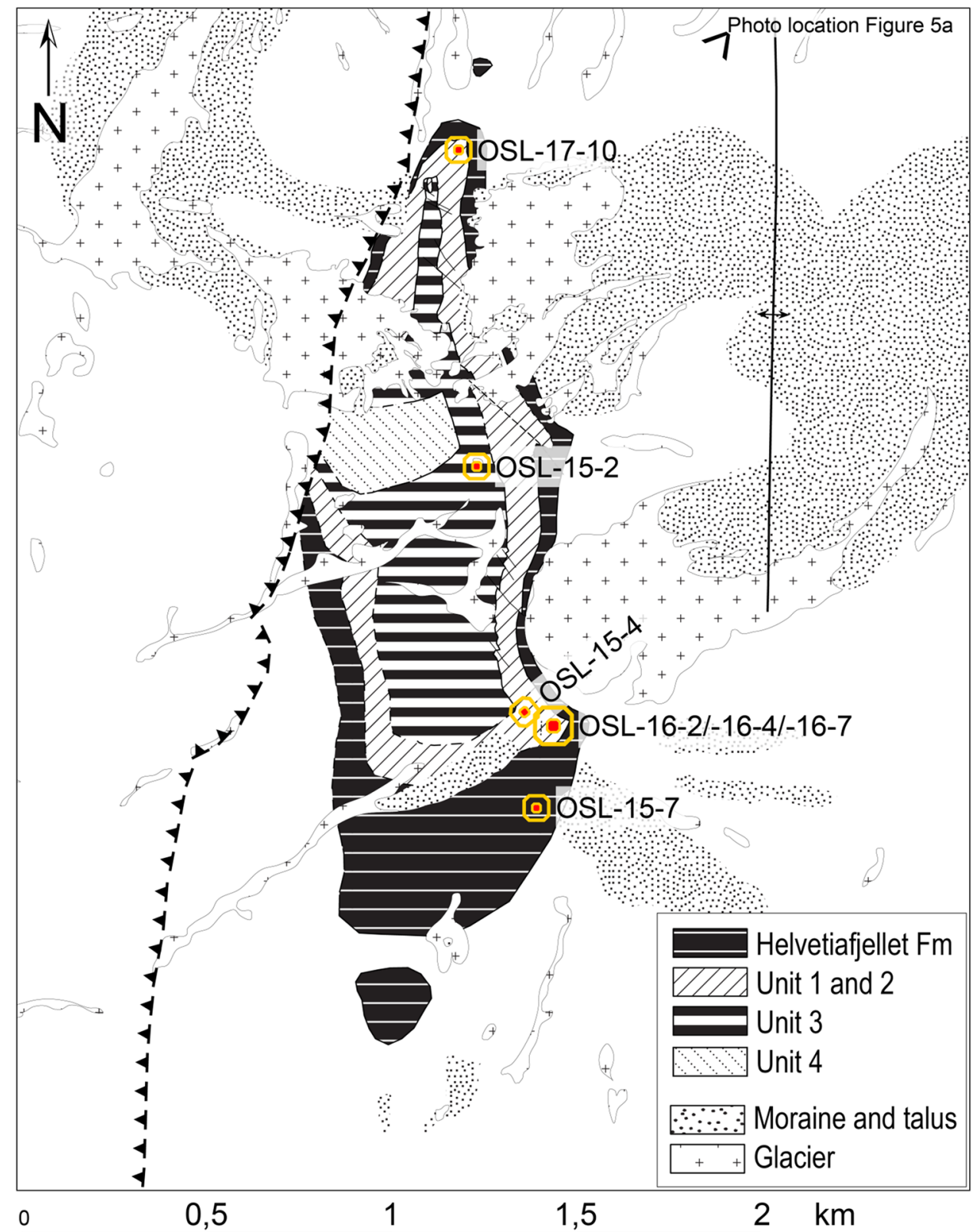

\section{Results}

\section{Geological mapping and structural configuration}

The mapped strata of the Sylfjellet succession extend from the northern ridge of the mountain at c. 480 masl to the southern ridge of the mountain at c. 630 masl and up to the summit of Syltoppen. The outcropping strata cover an area of $0.8 \mathrm{~km}^{2}$, and the maximum extent is $1.8 \mathrm{~km} \times 0.7 \mathrm{~km}$. The Sylfjellet succession overlies the c. $25 \mathrm{~m}$-thick cliff-forming sandstones of the Lower (Barremian to Aptian) Festningen Member of the Helvetiafjellet Formation [71-75]. Based on distinct sedimentological and lithological differences, the Sylfjellet succession was subdivided into four units including a coal-bearing unit at the base (Unit 1) overlain by a sandstone-dominated section (Unit 2), which is overlain by dark siltstones (Unit 3), and sandstones on the top (Unit 4). The present-day subaerial erosional surface defines the upper boundary of the mapped succession. The maximum stratigraphic thickness of the investigated succession (excluding the Lower Cretaceous succession) is c. $250 \mathrm{~m}$. Figure 3 shows the extent of the mapped area and elements that were changed compared to the existing geological map [10].

While the eastern part of the mapped area is overall well exposed, the western part is largely covered by debris and stratigraphic contacts on the map are inferred. The whole succession is well lithified except for some few highly weathered sections. 
The strata exposed on Sylfjellet forms the western limb of a reverse fault-bound anticline (Fig. 4). The layers are inclined and dip with $30^{\circ}-45^{\circ}$ toward the west in the summit ridge area. The mapped area is located in the WSFTB where the IYFZ bends northward, developing from an NNE-trending oblique dextral tear fault into a WNW-verging thrust fault zone consisting of several fold-thrust elements with upward throw toward the NE ([26], Fig. 2a).

The main vertical offset of the IYFZ is situated just west of Sylfjellet (f7 in Fig. 2e or fault 1 in Fig. 4) [12, 13, 31]. This fault is described as "a major steep fault zone that juxtaposes the Bravaisberget Formation to the west with the Janusfjellet Subgroup. (...) separation is consistent with a throw of 600 m" (p. 232 in [13]).

The assumed fault 2 in Fig. 4 (气 f8 in Fig. 2e) juxtaposes the black shales of the Janusfjellet Subgroup in the hanging block directly beside the Helvetiafjellet Formation and Units 1-4 in the footwall. Even though not directly exposed, significant vertical offset must be present also here in the form of a (oblique?) reverse fault. The presence of this fault is supported by abundant slickensides and fractured sandstones which are observed close to the col west of Sylfjellet, where the dip of the strata changes abruptly from westward to eastward. A fault is therefore inferred and modified from [10] (fault 2 in Fig. 4). The northern and southern extensions of the assumed fault are adapted from [11, 13]. West and north of Syltoppen, the fault-adjacent layers of Units 2 and 4 are pushed upward and kinked in the eastern footwall (see cross section in Fig. 4).

Unit 2 strata are folded into a syncline in the northwestern mapping area, which is considered evidence of drag along the major (oblique?) thrust to the west. Several small-scale faults are found in the Sylfjellet summit ridge area, both north and south of Syltoppen (Fig. 4).

\section{Sedimentological observations}

The character and definition of the units in the outcrop are shown in Fig. 5a, and the sedimentological observations are summarized in Fig. 6.

\section{Unit 1}

Unit 1 is c. $23 \mathrm{~m}$ thick at the southern ridge and c. $31 \mathrm{~m}$ at the northern ridge of Sylfjellet. The unit is dominated by sandstone, shale and coal, with pebbly layers occurring in between. It overlies the cliff-forming sandstone of the Helvetiafjellet Formation (Fig. 2) with a clearly visible, sharp contact. The lowest stratum of the unit shows lateral differences; in the southern field area, it consists of a grayish, plastic bentonite (tephra) bed, partly underlain by a few centimeters thick siltstone layer. In the northern map area, the bentonite is absent. Here, the lower contact is marked by either a distinct boundary between the Cretaceous sandstones and a coal seam or an up to $20 \mathrm{~cm}$-thick, graded sandy siltstone bed that contains floating granules and coal stripes. This bed forms the base of the coal seam. The basal contact is discussed separately below.

Wave ripple cross-lamination with Diplocraterion burrows occur in the northern outcrops of Unit 1 . The equivalent stratum on the southern ridge shows wave ripple crosslamination and rhythmic plane parallel bedding. The layers above consist of sandstone beds interbedded with organicrich mudrock and pebbly layers or floating pebbles. Ripple cross-lamination, rootlets and plant imprints are abundant. Thin coal layers occur in the upper part. A coal seam represents the uppermost part of Unit 1. It is overlain with a sharp boundary by the massive, cliff-forming sandstones of Unit 2 .

Unit 1 contains two well-developed, laterally consistent coal seams which are informally named here as the lower "Root" Seam and the upper "Krafse" Seam. The other coal layers appear laterally restricted. Both the Root and the Krafse seams are $\approx 115 \mathrm{~cm}$ thick at the southern ridge. In the northern part of the mapped area, coal thickness increases to $\approx 140 \mathrm{~cm}$ (Root Seam) and $\approx 180 \mathrm{~cm}$ (Krafse Seam).

Unit 1 is interpreted to represent mainly continental facies. However, above the Root Seam, a minor marine or brackish transgression is recorded, indicated by the Diplocraterion burrows resp. rhythmite horizon, which is tidal related. In conclusion, Unit 1 is continental to paralic, where the coal seams represent peat bodies in a coastal plain or alluvial environment. The lower boundary of the unit is erosive.

\section{Unit 2}

The cliff-forming, sandstone-dominated Unit 2 is $50-60 \mathrm{~m}$ thick. The lower boundary is sharp and defined by the first cliff-forming, massive sandstones above the Krafse Seam of Unit 1 . The unit consists of very fine- to fine-grained sandstone with varying mudstone content. Dominating sedimentary structures are hummocky cross-stratification, trough cross-stratification, ripple cross-lamination (predominanty symmetrical ripples) and plane-parallel lamination. Channelshaped geometries were observed as well as heterolithic sections, mud drapes and some minor rootlets. Conglomeratic lenses and floating pebbles are found in the sandstones. Bioturbation is abundant and burrows such as Maccharonichnus, Ophiomorpha and Schaubcylindrichnus were recognized.

The unit consists of four c. 10-17 m-thick coarseningupward (CU) units, resembling stacked parasequences. The CU units are typically highly bioturbated, with muddy to silty sandstones at the base and texturally more mature sandstones and conglomerates toward the top. The uppermost $\mathrm{CU}$ unit is capped by an up to $40 \mathrm{~cm}$-thick extraformational conglomerate.

Unit 2 is generally interpreted to represent shoreface and possibly mouth-bar deposits in a wave-dominated environment. Each $\mathrm{CU}$ unit records shoaling and successive 

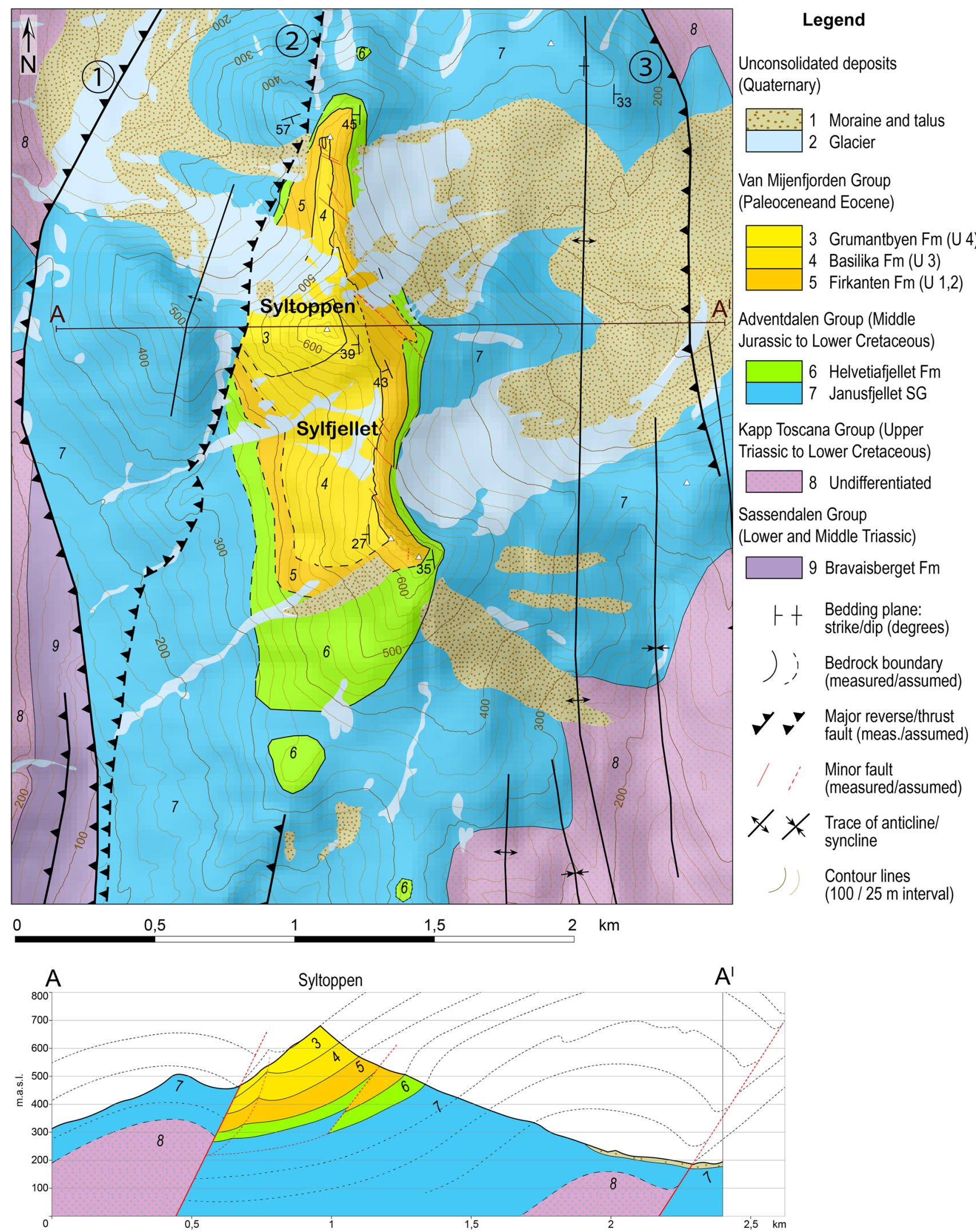
4Fig. 4 New map of the Sylfjellet area, scale 1:50,000 with cross section. Encircled numbers refer to faults mentioned in the text. Extent of map is shown in Fig. 2d. Based on the official map in the scale 1:100,000 from the Norwegian Polar Institute [10]. Contour lines and hillshade model constructed with the Digital Elevation Model from the Norwegian Polar Institute [98]. Base map is based on orthophotos and online map from the Norwegian Polar Institute [95]. $U$ Unit. All strike and slip measurements by the authors

progradation. A lag conglomerate tops the unit, representing a transgression to Unit 3.

\section{Unit 3}

Unit 3 reaches a thickness of c. $80 \mathrm{~m}$. The lower boundary is sharp and defined by the first dark siltstones on top of the cliff-forming, yellowish-grayish weathered sandstones and conglomerates of Unit 2. It consists of sandy siltstones with a darker color than both the underlying Unit 2 and the overlying Unit 4. Bioturbation is abundant and rounded chert pebbles occur. The upper contact is transitional and here defined by the first cliff-forming, silty sandstones of Unit 4. Unit 3 has an overall coarsening-upward trend.

Unit 3 is interpreted to represent muddy shelf conditions in the lower part of a regressive cycle which continues upward into the overlying sandstones of Unit 4.

\section{Unit 4}

Unit 4 forms the first outcrops above the considerably weathered Unit 3. The lower boundary is gradational and is defined here by the first observed cliff-forming and silty sandstones that are brighter in color than those of Unit 3. It consists of silty sandstones and glauconitic sandstones. Bioturbation is abundant, pebbles, mainly consisting of chert, occur locally. The lower part coarsens upward due to the less mud content of the sandstones. The best outcrops were mostly inaccessible due to their steepness; therefore the description is mainly based on the lower part of the unit and remote observations. Unit 4 has an estimated thickness of $90 \mathrm{~m}$ at Syltoppen. Since the upper boundary is defined by the present-day erosive surface, no statement can be made about the original thickness.

Unit 4 represents muddy shelf and pro-deltaic deposits. It forms the upper part of a regressive cycle, consisting of Units 3 and 4 combined.

\section{$\mathrm{U}-\mathrm{Pb}$ zircon dating of bentonite bed}

The plastic bentonite bed just above the base of Unit 1 (sample OSL 16-2, see Figs. 3 and 6) was analyzed to obtain an absolute age within the studied section. Results showed that it is a tephra layer of volcanic origin. Eight euhedral, slightly pinkish, high aspect ratio $(>1: 4)$, inclusion-rich zircons were selected for analysis. All zircon analyses are concordant to subconcordant, but have ${ }^{206} \mathrm{~Pb} /{ }^{238} \mathrm{U}$ ages that range from 61.93 to $61.54 \mathrm{Ma}$, with no overlap between the oldest and youngest zircons. The zircons have $\mathrm{Th} / \mathrm{U}$ ratios varying from 0.4 to 1.2 , but the variation is not correlated with age. We interpret ${ }^{206} \mathrm{~Pb} /{ }^{238} \mathrm{U}$ age of the four youngest, overlapping zircons as the best estimate for the depositional age of the bentonite at $61.527 \pm 0.045 / 0.050 / 0.090 \mathrm{Ma}(2 \sigma$; MSWD =1.37; Fig. 7). The remaining older zircons are interpreted as antecrystic, reflecting residence and zircon growth in a magma chamber. This means that the base of Unit 1 is of Paleocene age (earliest Selandian).

\section{The basal contact of Unit 1}

Important for the evaluation of the Sylfjellet succession is whether the contact between the underlying Helvetiafjellet Formation and Unit 1 is structural or sedimentary in nature. The answer will have implications for the structural interpretation of the WSFTB as well as for the correlation between Sylfjellet and the other Paleogene occurrences on Svalbard.

The contact is only well exposed and easy accessible at outcrops close to the southern and northern ridges of Sylfjellet. In the whole western part of the mapped area, it is covered by scree.

The lower boundary of Unit 1 is defined by up to $28 \mathrm{~cm}$ thick bentonite layer found in the southern area, locally underlain by a roughly $3 \mathrm{~cm}$-thick, graded, organic rich sandy siltstone (Figs. 6, 7). The unlithified, plastic bentonite (clay) has a tannic taste and pale gray and partly yellowish color from weathering of sulfur, forming jarosite. The upper part of the bentonite is permeated with inclined coaly stripes, interpreted as rootlets, overlain by a layer of organicrich black mudrock. The bentonite layer can be traced laterally for at least $80 \mathrm{~m}$.

The mechanically incompetent bentonite layer might be difficult to use as an indicator for strain due to its unlithified nature. Still, the in situ rootlets in the upper part are a clear sign for the clay being undisturbed. The rootlets are slightly inclined, which is interpreted to be a result of postsedimentary compaction of the clay.

In the northern mapping area, the bentonite layer is absent. The basal boundary is defined by a layer of coal rich mudrock with floating grains of sand to granule size, directly overlain by the lowest coal seam. Locally, the coal seam lies immediately over the sandstone of the Helvetiafjellet Formation. No signs of tectonic activity such as slickensides, faults or exceptionally fractured rocks were observed at or in direct vicinity to the contact. The coal has a blocky fracture pattern and shows no signs of strain action. In Svalbard mines, the immediate roof or floor of coal seams often act as small 

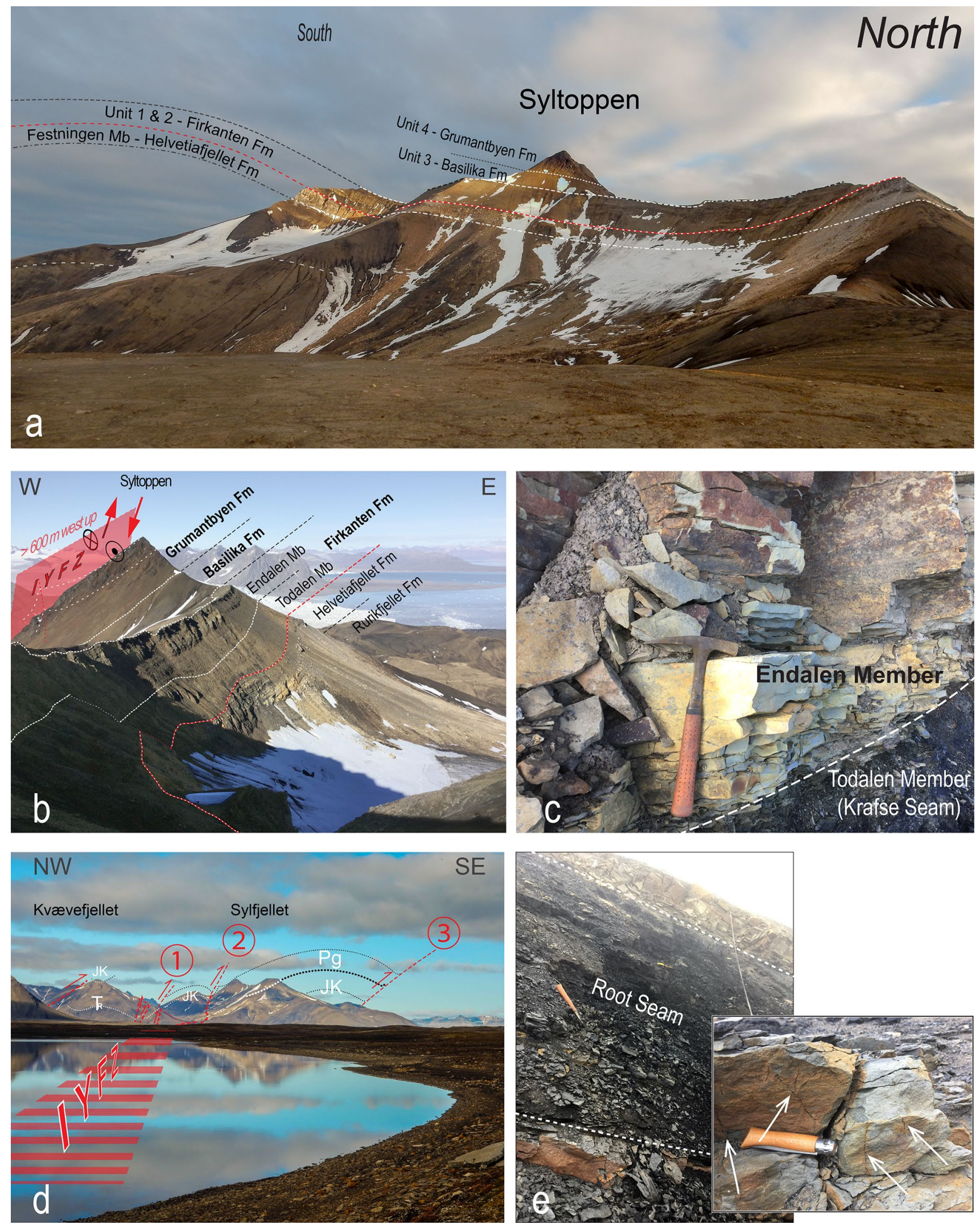
4Fig. 5 a Sylfjellet seen toward the southwest showing lithostratigraphic assignments of the mapped units. Extrapolation of the contacts indicates the structural interpretation. Photo location marked in Fig. 3. b Parts of the northern ridge of Sylfjellet and Syltoppen seen from the south showing the detailed lithostratigraphic assignment of the strata. The Isfjorden Ymerbukta Fault Zone (IYFZ) is schematically indicated west of Sylfjellet. The photo is taken close to sample location OSL-16-4 (see Fig. 3). c The contact between the Todalen Member and the Endalen Member of the Firkanten Formation at the northern ridge of Sylfjellet. The roof of the Krafse Seam (sample location OSL-16-4) marks the boundary to the sandstones of the Endalen Member, showing Macharonichnus isp. Hammer length $32 \mathrm{~cm}$. d Kvævefjellet and Sylfjellet seen from SSE. The location of the photographer is Straumsjøen on Erdmannflya (Fig. 2a), along strike with the IYFZ according to $[11,13,31]$, which is schematically indicated. The structural interpretation and stratigraphic assignment at Kvævefjellet is based on Braathen et al. [13]. Fault numbers as in Fig. 4. e The Root Seam in a steep outcrop at the northern ridge of Sylfjellet, picture is taken upwards at the sample location OSL-16-7. Floor and roof are marked by dotted lines. The small picture shows the abundantly occurring eponymous rootlets, marked by arrows. Knife is $10 \mathrm{~cm}$ long. Fm Formation, $M b$ Member, $T_{R}$ Triassic strata, $J K$ Jurassic/Lower Cretaceous strata, $P g$ Paleogene strata, IYFZ Isfjorden Ymerbukta Fault Zone

décollement surfaces (unpublished observations by the first author) - this has not been observed close to the lowest seam at Sylfjellet.

The absence of these strain indicators in both areas represents arguments for the contact being of sedimentary nature. The floating grains which are up to granule size have a conglomeratic appearance and can be interpreted as a transgressive lag, which is consistent with an undisturbed contact and support an erosional surface or a lacuna.

\section{Biostratigraphy}

Coal samples from Unit 1 were analyzed for palynomorphs to obtain a relative age of the deposits. The maceration residues of the two coal samples OSL-16-4 and OSL-16-7 (Figs. 3, 6) consist almost entirely of phytoclasts. In sample OSL-16-4, only opaque phytoclasts are included and palynomorphs are completely absent. In sample OSL-16-7, which is composed of mainly translucent phytoclasts, only one well-preserved pollen grain was found (Fig. 8a). It is a small triporate pollen with a diameter of only $15 \mu \mathrm{m}$, a nearly circular equatorial outline and a smooth exine. Palynological taxa with comparable morphological features are known from Eocene occurrences in Europe and described, for example, as Celtipollenites laevigatus [76]. As possible parent plants in addition to Cannabaceae (Celtis), Moraceae and Urticaceae are considered, because modern Celtis pollen do not show a smooth exine [76]. As Triporates, Types A and F, Manum [77] described similar pollen from coal of the Longyearbyen area and suggested a betulaceous or myricaceous relationship. Nevertheless, despite the uncertain botanical classification, an angiosperm origin of the pollen grain is obvious.
The similar morphotypes from Spitsbergen [77] and Europe [76] are from Paleogene sequences. In Central Europe, these taxa even occur in the Miocene [76]. Despite the minor database, the proof of such a morphotype indicates a post-Cretaceous age for the succession, especially as the Upper Cretaceous as well as the reworked Cretaceous palynoflora of Spitsbergen $[36,78]$ has a distinctly different composition and morphotypes like the one described here are missing.

Several macroscopic plant fossils were found in Unit 1 on the northern ridge of Sylfjellet (sample OSL-17-10 in Figs. 3, 6; photographs in Fig. 8b and Online Resource 2). Four specimens were collected or photographed in the field. The classification given here is purely based on analysis of the photographs and might therefore be deficient. The following fossils have been discovered: Sequoia langsdorfii (Brongniart) Heer 1855 with the age range of Paleocene to Pliocene [79], Osmunda macrophylla Penhallow 1908 with the age range of late Paleocene to early Eocene [80] (Fig. 8b), Metasequoia occidentalis (Newberry) Chaney 1951 with the age range of Upper Cretaceous to Pliocene (early Paleocene to late Eocene on Spitsbergen) [81].

For foraminifera, the two analyzed samples were from Unit 2 and Unit 3. A total of 18 foraminifera were discovered in sample OSL-15-2 and 14 individuals in sample OSL-15-4 (Figs. 3, 6). Due to their poor preservation, many of the foraminifera were only identifiable to genus level. In sample OSL-15-2, these were Saccammina sp., Haplophragmoides sp. and Trochammina sp. In sample OSL-15-4, the recovered genera were Rhizammina sp., Saccammina sp., Lagenammina sp., Haplophragmoides sp., Recurvoides sp., Trochammina sp., and ?Verneuilinoides sp. In the two samples, only three species of foraminifera were preserved well enough to be identified to species level. Ammodiscus cf. glabratus occurred in sample OSL-15-2 and Repmanina charoides was found in sample OSL-15-4, while Glomospira gordialis occurred in both samples. Unfortunately, these foraminifera all have a long stratigraphic age range and are therefore not age diagnostic. All of the recovered individuals are of the agglutinating type, which indicates that the depositional environment of the sediments in which they were found was stressed at the time, for example by high energy.

\section{Vitrinite reflectance}

To evaluate the thermal maturity of the studied strata and to compare it to other areas within the CTB, vitrinite reflectance was analyzed from the outcropping coal seams. As described by Marshall et al. [53], Paleocene coals in Svalbard are often perhydrous, which can cause vitrinite reflectance suppression by bitumen impregnation. To account for this effect and get the most representative result, the two coal seams from Unit 1 were sampled as detailed as possible 
Sylfjellet south ridge

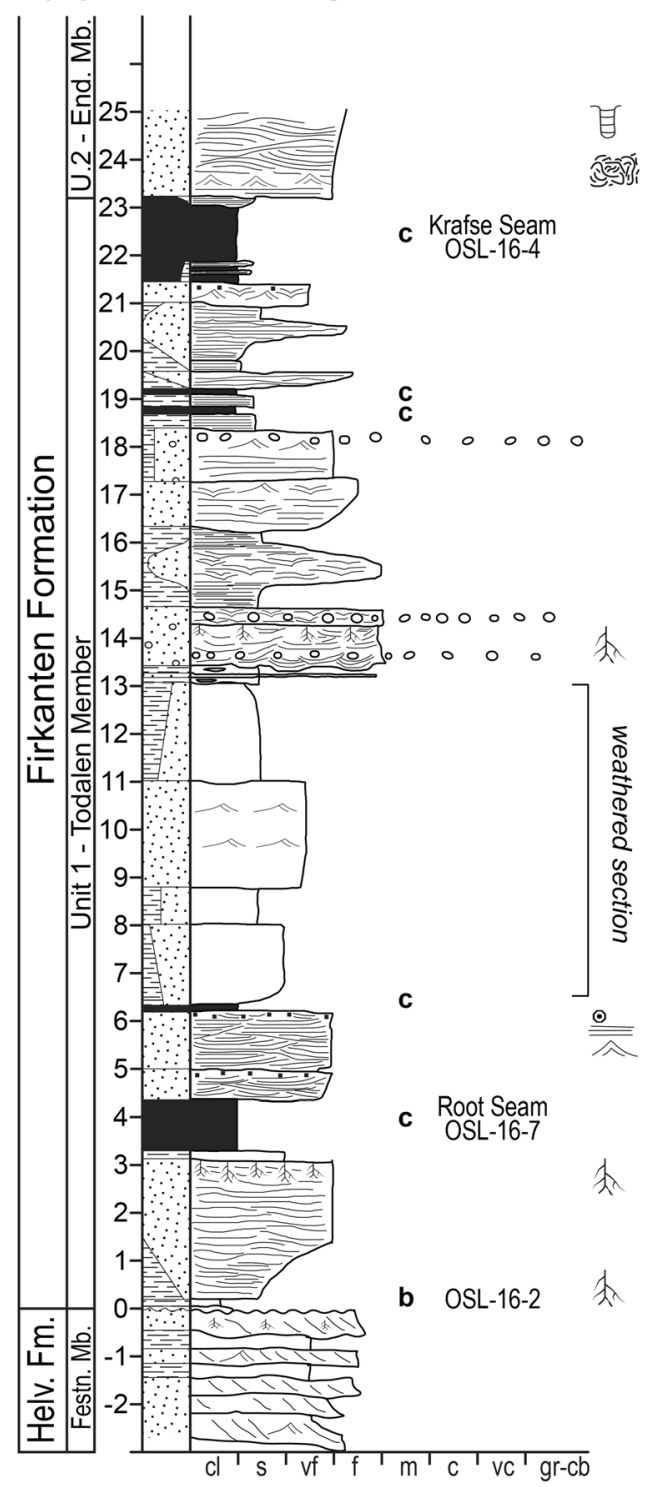

\section{Legend}

\begin{tabular}{|c|c|c|c|}
\hline OSL-16-2 & Sample number & C & Coal seam \\
\hline 公 & Wave ripples & b & Bentonite / tephra \\
\hline 必 & Ripple structures & 本 & Rootlets \\
\hline$\approx$ & Heterolithic facies & 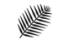 & Gymnosperm plant fossil \\
\hline$\equiv$ & Plane parralel lamination & sss & Bioturbation \\
\hline$\sim$ & Hummocky cross stratification & 目 & Ophiomorpha \\
\hline$\circ$ & Granules / pebbles & 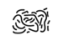 & Macaronichnus \\
\hline : & Coal fragments & $\infty$ & Schaubcylindrichnus \\
\hline$\odot$ & Sideritic nodules/beds & U & Diplocraterion \\
\hline
\end{tabular}

\section{Composite log Sylfjellet}

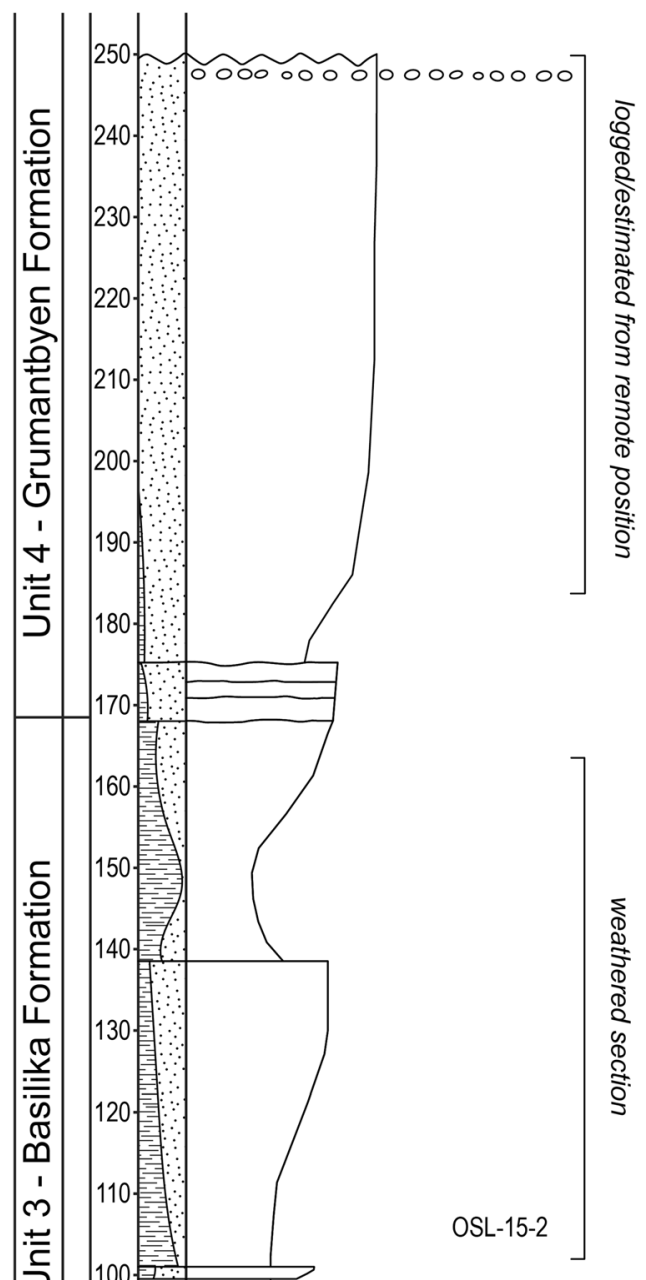

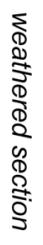

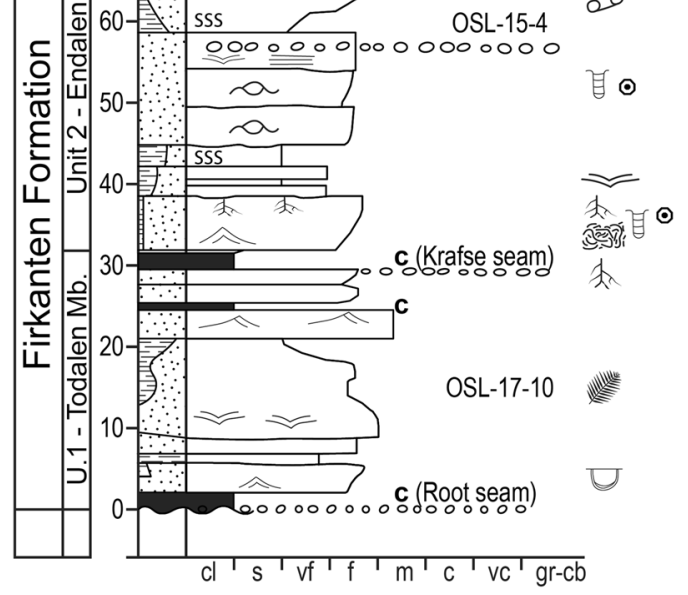


4Fig. 6 Left: $\log$ of the Todalen Member at the southern ridge of Sylfjellet. Right: Composite log of the Sylfjellet section composed of the following sections: Todalen Member: Sylfjellet north ridge; Endalen Member: Sylfjellet south ridge; Basilika and Grumantbyen formations: Syltoppen south ridge. Helv. Fm. Helvetiafjellet Formation, Festn. Mb. Festningen Member, U. Unit, End. Mb. Endalen Member

in the field. The lower Root Seam has a total thickness of $115 \mathrm{~cm}$ and was sampled from roof to floor with 12 samples (combined sample OSL-16-7 in Figs. 3 and 6). The upper Krafse Seam with a similar thickness yielded 11 samples (combined sample OSL-16-4 in Figs. 3 and 6). As shown in Fig. 9, the effect of random reflectance $\left(R_{\mathrm{r}}\right)$ suppression toward the top of the seams appears clear and is in coherence with the observations by Marshall et al. [53]. Accordingly (and confirmed by Uguna et al. [82]) the most accurate values for $R_{\mathrm{r}}$, reflecting the "real" thermal maturity, are found at the base of the seams where vitrinite remained mostly unaffected by the suppression effect by bitumen impregnation. Here, $R_{\mathrm{r}}$ is in the range of $0.67 \%$ (Root Seam) and $0.63 \%$ (Krafse Seam). The stratigraphic distance between these is $18 \mathrm{~m}$ and thus negligible in this context.

Samples of Lower Cretaceous coal came from the c. $10 \mathrm{~cm}$-thick coal seam in the Helvetiafjellet Formation (sample OSL-15-7, Fig. 4), which lies below Unit 1 at the southern ridge of Sylfjellet. The sample location at 580 masl lies ca. 70 altitude meters below the coal seams of Unit 1 with a horizontal distance of $220 \mathrm{~m}$. The stratigraphic difference is estimated to be less than $20 \mathrm{~m}$ to the Root Seam. The measured random reflectance $R_{\mathrm{r}}$ is $0.62 \%$, a possible reflectance suppression effect could not be examined.

\section{Discussion}

\section{The original position of the Sylfjellet succession}

Any reconstruction of the Paleocene paleogeography requires a structural restoration which will make it possible to relate the Sylfjellet succession to other, tectonically less disturbed Paleocene strata as the lower Van Mijenfjorden Group in the CTB. The closest outcrop comprising strata of the Van Mijenfjorden Group is at Erdmannflya where the Paleocene Firkanten, Basilika and Grumantbyen formations are preserved east of the IYFZ [31] (Fig. 2). The closest area where the CTB occurs relatively unfolded and unthrust is at Bohemanneset (Fig. 2), where the Lower Cretaceous Helvetiafjellet and Rurikfjellet formations are exposed.

The connection between those CTB outcrops north of Isfjorden and the main part of the CTB south of Isfjorden has been examined by Blinova et al. [29]. Seismic transects in Isfjorden show thrust faults which are more or less parallel with the general strike of the WSFTB, similar to what is observed south of Isfjorden. No strike slip faults or faults with other orientations were found. Consequently, the Paleocene deposits at Erdmannflya and the Lower Cretaceous deposits at Bohemanneset can structurally be interpreted in connection to the CTB synclinorium, representing its northernmost outcrops. Both are situated east of the IYFZ where significant dextral oblique strike slip movement occurred. They can therefore be used as spatial reference areas representing the CTB, when compared with strata incorporated in the WSFTB, such as Sylfjellet. The question if Sylfjellet is situated northwest, southeast or within the IYFZ is not straightforward to answer. A complex strain pattern northwest of Sylfjellet is well documented [13] and possibly most of the IYFZ strain took place here. For the area between Sylfjellet and Bohemanneset, the character of tectonic disturbance is debated: While some authors [10, 12, 13] describe the area as dominated by folding, others $[5,11,26]$ show several thrusts east of Sylfjellet. Irrespective of the manner of tectonic movement, the fact that the Helvetiafjellet Formation crops out at both Bohemanneset and Sylfjellet shows that the vertical offset accounts to c. $600 \mathrm{~m}$.

The maximum lateral movement that the mapped unit has experienced can be estimated based on available literature. The horizontal dextral offset of the IYFZ has been estimated to be between 5 and $10 \mathrm{~km}$ by Braathen et al. [13] and $8 \mathrm{~km}$ by Piepjohn and van Gosen [11]. Bergh et al. [26] restored two folded and thrust cross sections on Oscar II Land and estimated shortening to be approximately $45 \%$ as a minimum estimate. These numbers allow a tentative estimate of the original position relative to the Bohemanneset outcrops; the Sylfjellet succession would be maximum $5 \mathrm{~km}$ further west to restore folding and thrusting (45\% of the distance between Sylfjellet and Bohemanneset) and $8 \mathrm{~km}$ further SSW to restore strike slip movement along the IYFZ. That places Sylfjellet maximum $12 \mathrm{~km}$ southwest of the present position, or $10 \mathrm{~km}$ northwest of the Paleocene Erdmannflya strata (indicated in Fig. 2a). Consequently, the Sylfjellet succession has not been located far beyond its existing position relative to the $\mathrm{CTB}$.

\section{The age of the Sylfjellet succession and its relation to the Van Mijenfjorden Group}

Absolute dating and biostratigraphy revealed in the present study show a Paleocene age for the Sylfjellet succession, whereas all previous publications (including maps and books, e.g., [2, 4, 7, 9-14, 27, 28, 33, 49, 83, 84]) show a Mesozoic age for the summit region of Sylfjellet. It is therefore pertinent to evaluate the dating results and question how the mapped units relate to other Paleocene deposits on Svalbard. 

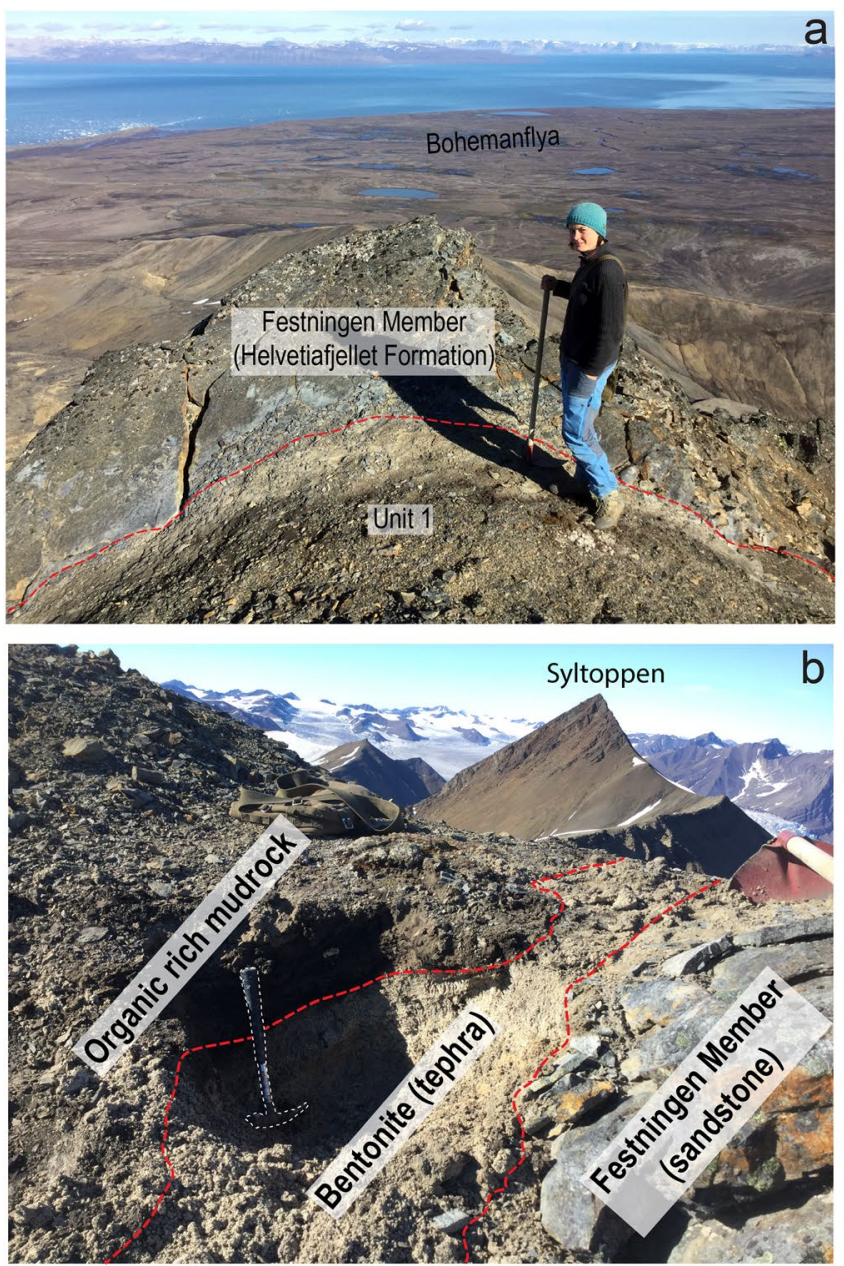

Fig. 7 a One of the authors $(\mathrm{TH})$ is standing at the contact between the cliff-forming sandstones of the Helvetiafjellet Formation and the mapped unit. The gray layer at her right foot is the plastic bentonite layer. View toward East. b Close up of the basal layers of the unit and the uppermost part of the Festningen Member (Helvetiafjellet Formation). View is toward north and hammer length is $32 \mathrm{~cm}$.
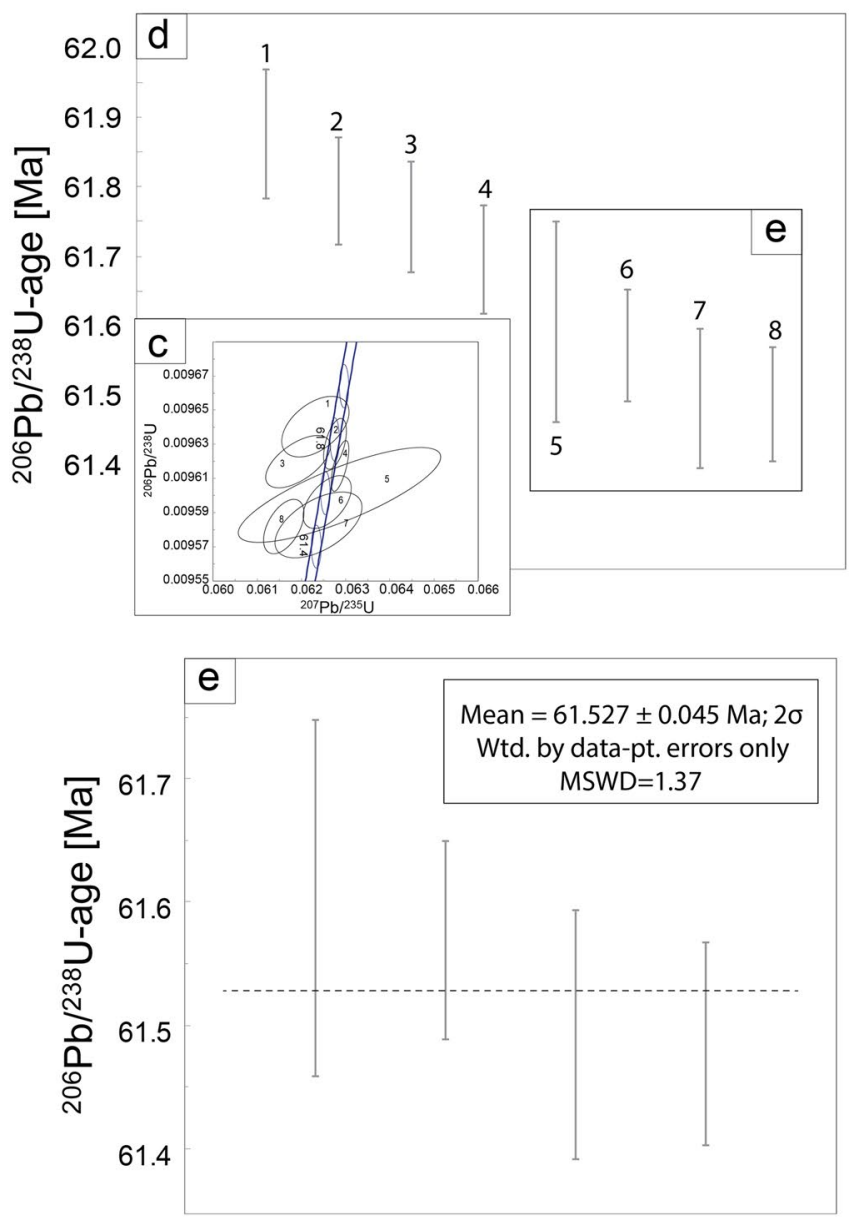

Sample location is shown in Fig. 3. Right side: $\mathrm{U}-\mathrm{Pb}$ zircon data for OSL-16-2. c Concordia diagram of all zircon analyses. d Plot showing ${ }^{206} \mathrm{~Pb} /{ }^{238} \mathrm{U}$-ages of individual analyses. e Plot showing ${ }^{206} \mathrm{~Pb} /{ }^{238} \mathrm{U}$ ages of the zircon population used to calculate the age of the bentonite. All data point errors are $2 \sigma$. See also Online Resource 1
Fig. 8 a Triporate angiosperm pollen grain (?Celtipollenites laevigatus Thiele-Pfeiffer 1980) of possible betulaceous or myricaceous origin, sample OSL-16-7. Scale bar: $10 \mu \mathrm{m}$. b Leaf of Osmunda macrophylla Penhallow 1908, sample OSL17-10. Scale bar units $1 \mathrm{~mm}$. More plates in Online Resource 2
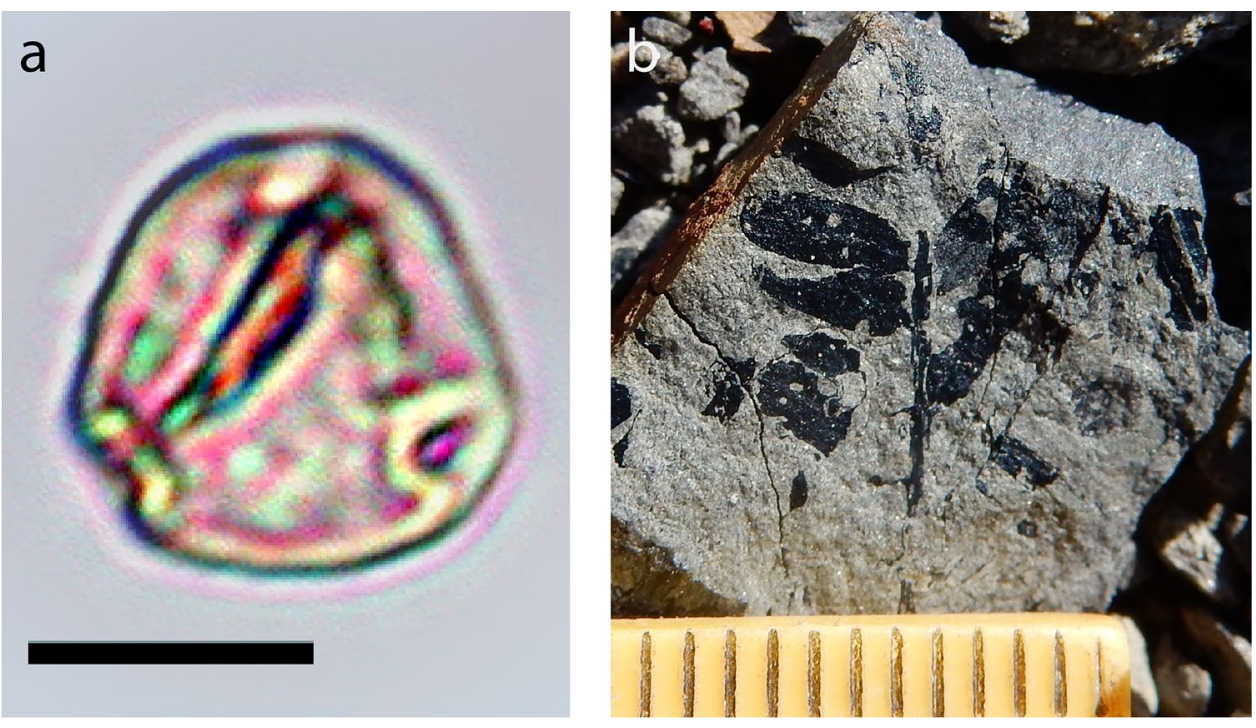


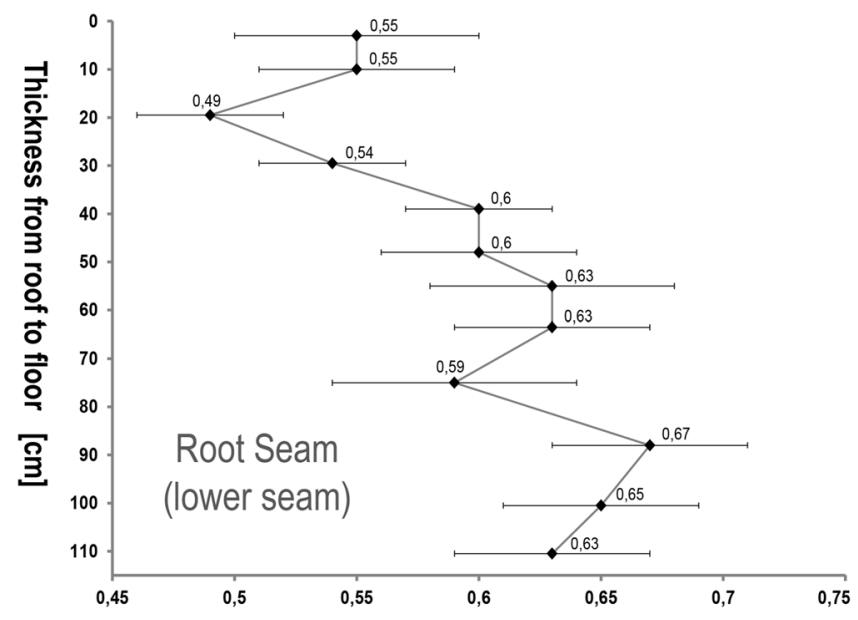

Fig. 9 Random vitrinite reflectance data $\left(R_{\mathrm{r}}\right)$ from the two main coal seams in the Firkanten Formation at Sylfjellet. Root Seam $\triangleq$ sample OSL-16-7; Krafse Seam $\triangleq$ sample OSL-16-4. Every data point is based on 100 measurements. Both seams show clearly the effect of $R_{\mathrm{r}}$ suppression caused by bitumen impregnation, as previously shown by

The U-Pb age of $61.527 \pm 0.045 \mathrm{Ma}$ for the bentonite layer at the base of Unit 1 is similar to the age that Jones et al. [23, 85] report from a tephra layer of the Todalen Member (Firkanten Formation), which occurs at several locations between Longyearbyen and Svea. They conclude that their samples all derive from the same eruption from the volcanic suite of the Kap Washington Group in northeastern Greenland. With a mean age of $61.596 \pm 0.028 \mathrm{Ma}$ for the tephra bed dated by Jones et al. [23], the Sylfjellet-tephra is just overlapping this age and could represent tephra from the same volcanic eruption.

In all locations reported by Jones et al. [23], the tephra layer occurs between 7.1 and $11.7 \mathrm{~m}$ above the basal Paleogene unconformity in a continental to paralic environment, close to the lowest coal seam [23]. This tephra layer has also been mapped at Ispallen (Fig. 2a), where it occurs between 1 and $7 \mathrm{~m}$ above the basal unconformity [86]. That indicates that Paleocene deposition occurred in a paralic belt with an isochronal coast line reaching almost $100 \mathrm{~km}$ from Ispallen to Sylfjellet. This interpretation is in conflict with the model by Lüthje [57] which shows significant onlap of the Todalen Member on the Lower Cretaceous strata between Svea and Longyearbyen and a clear backstepping development and younging of deposits toward the north for the Todalen Member. Our interpretation is in better agreement with the paleogeographic reconstruction by Nagy [56], who postulates a continuous paralic belt in the area from Schönrockfjellet (Fig. 2) via Svea and Longyearbyen to north of Isfjorden during the early Paleocene. We therefore argue that Unit 1 was deposited as part of the same sedimentary system as the Todalen Member.

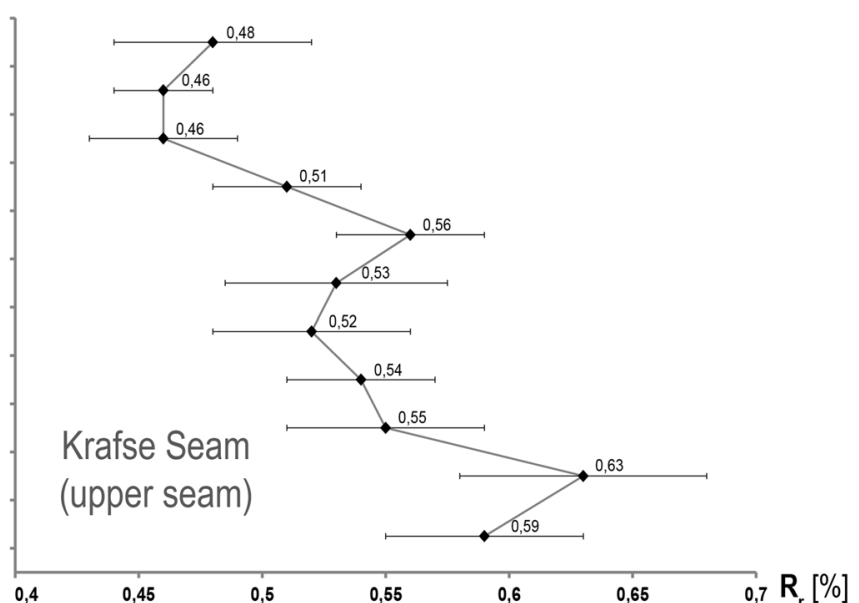

Marshall et al. [53] for other places within the CTB. The most representative values, showing the thermal maturity, are found at the base of the seams. Error bars show double standard deviation for every set of 100 measurements

\section{Lithostratigraphic assignments}

\section{Units 1 and 2: Firkanten Formation}

The Todalen Member in the area east of Longyearbyen represents a deltaic or coastal plain environment, which varies in thickness from 18 to more than $50 \mathrm{~m}$, and contains three to five coal beds [87, 88]. At Sylfjellet, Unit 1 has a thickness of 23-31 m. With 2-4 coal beds, of which two have significant thickness, and one level indicating tidal or marine influence, there is sedimentological similarity to the Todalen Member in the Longyearbyen area. The matrix-supported granules at the base of the coal seam on the northern ridge of Sylfjellet would represent the Grønfjorden Bed [9] of the Todalen Member.

The Endalen Member thickens westward from $45 \mathrm{~m}$ at Konusen $12 \mathrm{~km}$ northeast of Longyearbyen to $120 \mathrm{~m}$ at Grumantbyen $12 \mathrm{~km}$ southwest of Longyearbyen. It consists of four to five sandstone intervals each with a clear coarsening-upward trend, and represents a barrier shoreline in a shallow-marine environment [22]. At Sylfjellet, the sandstone-dominated Unit 2 is $50-60 \mathrm{~m}$ thick and consists of four coarsening-upward cycles, showing the same sedimentological characteristics as the Endalen Member in the Longyearbyen area.

Units 1 and 2 together are 70-80 m thick, which is comparable to the Firkanten Formation in the area northeast of Longyearbyen according to, e.g., Kellogg [12] and Bruhn and Steel [22]. A unit comparable to the marine mudstonerich Kolthoffberget Member, the third and the most distal member of the Firkanten Formation, was not observed at Sylfjellet; again this is similar to the Longyearbyen area. 
Only limited information is available and no sedimentological logs are published from Erdmannflya, the outcrop being located closest to Sylfjellet. Kellogg [12] states that $44 \mathrm{~m}$ Tertiary clastic beds overlie the Cretaceous, "similar to the lower Firkanten Formation as it is developed between Grumantbyen and Longyearbyen" (p. 476). Livšic [14] as well as the unpublished thesis of Schaupeter and Struck [89] reports a thickness of $110 \mathrm{~m}$ for the whole Firkanten Formation. The latter describes two units at Erdmannflya (i.e., Todalen and Endalen members) with thicknesses of $45 \mathrm{~m}$ and $65 \mathrm{~m}$, respectively.

The thickness of the Todalen Member varies significantly even over short distances, possibly due to the topography of the peneplain after the Late Cretaceous/Paleocene erosion, but lies in general in the range of c. $20-60 \mathrm{~m}$ in the northeastern part of the CTB [87]. The Endalen Member has a more constant thickness distribution with a clear thickening trend toward the west within the CTB. Unit 2 can therefore be compared with the Endalen Member in the Longyearbyen area or at Erdmannflya. Based on the analysis above it is concluded that Unit 1 can be is correlated with the Todalen Member of the Firkanten Formation due to the age, similarities in lithology, sedimentary expression, thickness distribution, and relation to Unit 2 . Unit 2 is correlated with the Endalen Member of the Firkanten Formation due to similarity in lithology, internal geometry, thickness, and relation to the over- and underlying units.

\section{Unit 3: Basilika Formation}

The Basilika Formation close to Longyearbyen consists of black and gray shale with thin interbeds of sandstone and occurring dropstones [31]. It is organized in repeated coarsening-upward successions and has a general large-scale coarsening-upward trend to the upper boundary which is defined by the transition to the greenish sandstone of the Grumantbyen Formation [88]. The lower boundary to the sandstones of the Endalen Member is normally sharp.

Unit 3 has similar internal characteristics, constituting a sharp lower boundary and a transitional boundary to Unit 4. The thickness of $80 \mathrm{~m}$ is comparable to the Basilika Formation at the coastal cliffs on the southern side of Isfjorden [14] and at Carolinefjellet, $10 \mathrm{~km}$ northeast of Longyearbyen [88]. For Erdmannflya, Livšic [14] reports a thickness of $150 \mathrm{~m}$, while Schaupeter and Struck [89] report $55 \mathrm{~m}$. Due to the gradual character of the boundary to the overlying Grumantbyen Formation, the formation can be defined in various ways, hence the differences in thickness. In addition, the thickness differences on Erdmannflya might be caused by tectonic disturbance in the area. Thus it appears difficult to use the thickness from Erdmannflya for comparison. Firkanten and Basilika formations together show a clear thickening trend toward the southwest from $150 \mathrm{~m}$ northeast of
Longyearbyen to more than $400 \mathrm{~m}$ at Barentsburg [12, 14, 22]. The thickness of 160 m of units 1,2 and 3 is comparable to the Firkanten and Basilika formations at the northeastern margin of the CTB. In conclusion, Unit 3 is correlated with the Basilika Formation due to similarities in lithology, sedimentological character, thickness, and relation to underlying Units 2 and 3 and overlying Unit 4.

\section{Unit 4: Grumantbyen Formation}

Due to the present-day erosive upper surface of Unit 4, thickness cannot be used for comparative purposes. The Grumantbyen Formation in the Longyearbyen area is a cliffforming sandstone unit which constitutes the plateaus of many mountains in Nordenskiöld Land. It consists of greenish, glauconite-bearing, massive and bioturbated sandstone with rare dropstones [88]. The lower boundary is transitional from the Basilika Formation. Unit 4, forming the peaky summit of Syltoppen (Figs. 1 and 5), has a similar character. Both lithology, glauconite content, lower boundary, and the sedimentological and intensively bioturbated character are similar to the Grumantbyen Formation in the Longyearbyen area. In conclusion, Unit 4 can be correlated with the Grumantbyen Formation due to similarities in lithology, amount of bioturbation and the sedimentological development from the underlying Unit 3.

Lithostratigraphy, sedimentology, paleoenvironment, age, regional and paleo-regional relations all suggest that the Sylfjellet succession has been deposited in the same basin as the lower Van Mijenfjorden Group, which is found in the CTB. The Sylfjellet succession should consequently not be treated as a separate group. Therefore, the Sylfjellet succession is here assigned lithostratigraphically to the lower part of the Van Mijenfjorden Group, thereby adding a fourth structural outlier to the group alongside the NyÅlesund Subgroup, the outcrop west of Grønfjorden and the $\emptyset y$ rland Graben deposit.

\section{Origin and extent of the basal hiatus of the Paleogene Sylfjellet succession}

At Sylfjellet, the Paleocene Firkanten Formation rests on the Barremian-Aptian Helvetiafjellet Formation. This regional hiatus is known to increase in magnitude northward within the CTB, with the Firkanten Formation lying directly on top of the upper Albian strata of the Carolinefjellet Formation deposits in southern Spitsbergen [90], middle Albian strata in southeastern Spitsbergen [91], Aptian strata in Central Spitsbergen [39], upper Aptian in the Longyearbyen area and lower Aptian at Erdmannflya [12]. In the northernmost location of Ny-Ålesund, the Van Mijenfjorden Group rests directly on Lower Triassic and Upper Permian strata [92]. This overall northwards increasing hiatus records uplift in 
the north during the Late Cretaceous to earliest Paleocene, likely related to thermal doming and initial rifting in the Eurasian Basin north of Svalbard and Greenland [7].

Sylfjellet therefore represents the only known locality where the Firkanten Formation rests directly on the Helvetiafjellet Formation. Figure 10 gives a summary of published relative and absolute ages for both the strata below and above the hiatus. The sub-hiatal strata successively age northward, showing northward increasing erosion during the Late Cretaceous and earliest Paleocene. The new observation at Sylfjellet extends both the general trend of increasing hiatus northwards and the distribution of the Van Mijenfjorden Group beyond its known outcrop limits. It also supports the former assumption that the Ny-Ålesund Subgroup is a correlative part of the lower part of the Van Mijenfjorden Group and that the depositional basin exceeded the extent of the CTB by far.

In the structural outlier of the Øyrland Graben, Krutzsch [78] presented Upper Cretaceous microflora from the strata that have officially been assigned to the Firkanten Formation in Dallmann [9]. Since reworked Upper Cretaceous palynomorphs are not unusual in the Paleocene of Svalbard, Smelror and Larssen [90] doubt an Upper Cretaceous age, but do not present evidence for a Paleocene age of the $\emptyset$ yrland deposit. The age is therefore added as questionable in Fig. 10.

\section{Tectono-sedimentary implications of the thermal maturity of coals}

In our dataset, the stratigraphic distance between all analyzed coal seams is less than $50 \mathrm{~m}$. That means that a potentially recorded paleo-geothermal vitrinite reflectance gradient would be below the measuring accuracy for this interval, assuming that both Cretaceous and Paleogene coals share the same burial history. The $R_{\mathrm{r}}$ representing the thermal maturity of the coals on Sylfjellet (both Cretaceous and Paleogene) is in the range between $0.62 \%$ and $0.67 \%$. This is comparable to the coals of the Firkanten Formation at Operafjellet close to Longyearbyen where Marshall et al. [53] measured a reflectance of $0.68 \%$.

The $R_{\mathrm{r}}$ values from Sylfjellet are surprising because Paech and Koch [50] report similar values from Bohemanneset $\left(0.68 \% R_{\mathrm{r}}\right.$, classified as"high quality data") where coal seams from the Helvetiafjellet Formation are exposed at sea level. The height difference between these coals of same stratigraphic level is c. $600 \mathrm{~m}$ across a horizontal distance of only $9 \mathrm{~km}$.

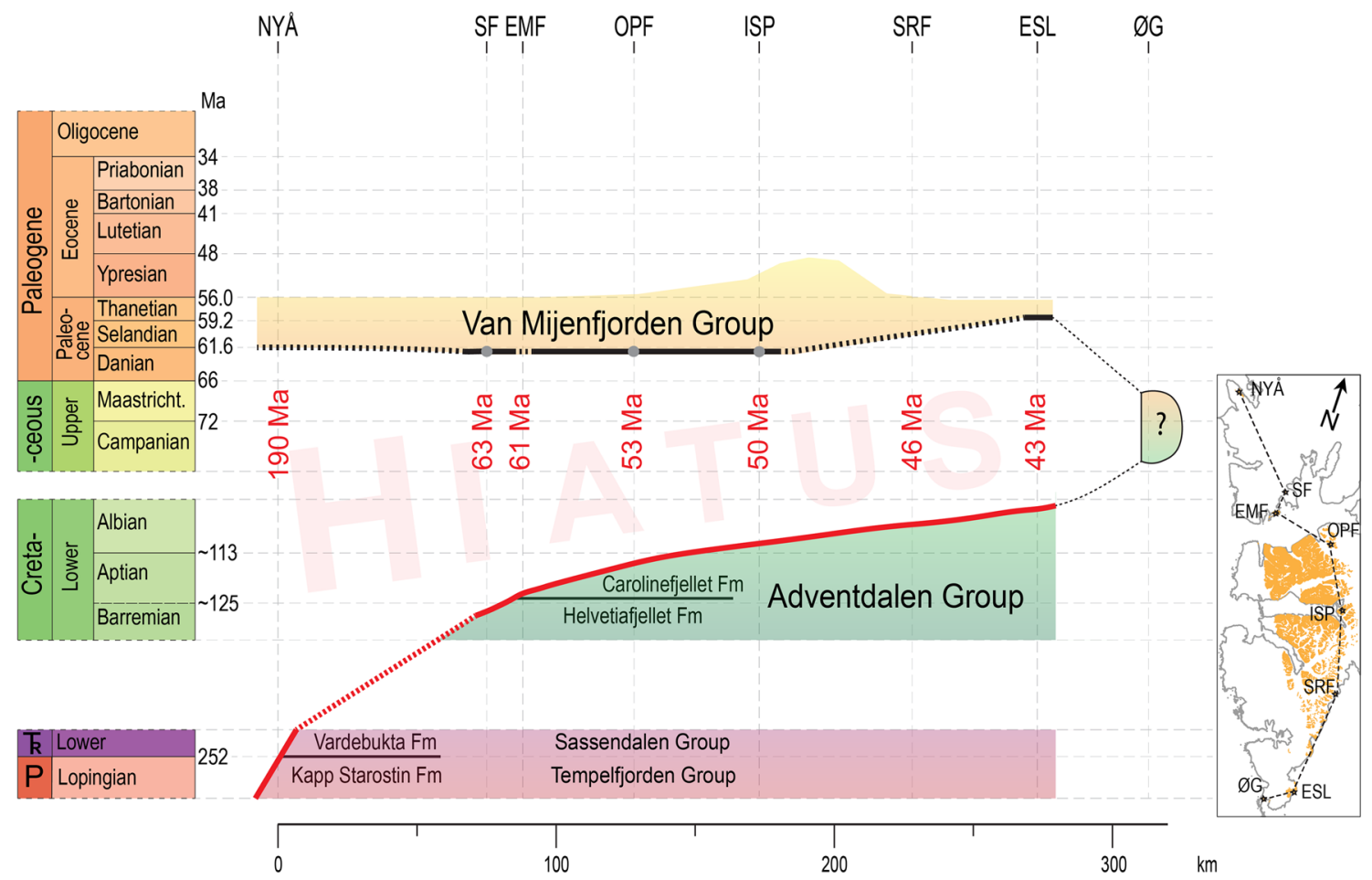

Fig. 10 Wheeler chart showing the Paleozoic to Cenozoic hiatus below the Van Mijenfjorden Group on Svalbard. Continuous line: dating available; dotted line: no dating available; gray spot on black line: absolute dating. NYA Ny-Ålesund, SF Sylfjellet, EMF Erdmann- flya, $O P F$ Operafjellet, ISP Ispallen, SRF Schönrockfjellet, ESL Eastern Sørkapp land, $\varnothing G$ Øyrlandet Graben. Age references are based on data by $[12,23,39,72,73,78,84,90,92]$ and this study. Stratigraphic chart after [99]. Base map (C) Norwegian Polar Institute 
An overview of Svalbard $R_{\mathrm{r}}$-data in Paech and Koch [50] indicates that thermal maturity of the Cretaceous and Paleogene rocks is a result of the thickness of overburden. The strata from both systems have a linked geothermal history, and it can thus be assumed that the coals from both Bohemanneset and Sylfjellet share the same thermal and burial history responsible for the final coalification.

These observations permit the following inferences about the interplay of burial (i.e., thermal) and structural history of the area: Vitrinite reflectance of the Paleogene strata at Sylfjellet is comparable to other areas of the CTB where maximum overburden has been estimated to at least $2 \mathrm{~km}$ ([53] and references herein). This implies a burial of at least $2 \mathrm{~km}$ also for the Firkanten Formation at Sylfjellet, which is more than the stratigraphic thickness of the entire Van Mijenfjorden Group.

From different areas south of Isfjorden. a vertical $R_{\mathrm{r}}$ gradient of $0.3-0.37 \% / \mathrm{km}$ has been reported [41, 50, 53, 93] and can thus be assumed for the Sylfjellet area. If a thermal equilibrium would have been re-established after folding and thrusting, a vitrinite reflectance difference of $0.2-0.24 \%$ would be expected between Bohemanneset and Sylfjellet, and not $0.01-0.06 \%$ as measured.

Two conclusions can therefore be drawn based on the data: (1) maximum burial, accounting for more than $2 \mathrm{~km}$ overburden above the Todalen Member, predates folding and thrusting in this area, and (2) fast erosion of the folded and thrust overburden prevented the formation of a new, balanced geothermal gradient within the uppermost $3 \mathrm{~km}$ of the lithosphere.

\section{Conclusions}

Based on detailed structural mapping, sedimentological descriptions, as well as relative and absolute age analyses of strata exposed on the mountain of Sylfjellet, we conclude the following:

- Both micro- and macrofossil content and absolute dating of a tephra layer located at the base of the succession show that the summit region of Sylfjellet consists of Paleogene sedimentary rocks. The tephra layer yielded a ${ }^{206} \mathrm{~Pb} /{ }^{238} \mathrm{U}$ age of $61.527 \mathrm{Ma}$ which is earliest Selandian.

- Based on the age data and sedimentological characteristics, the strata are hereby assigned to the Paleocene Firkanten, Basilika and Grumantbyen formations and therefore lithostratigraphically belong to the Van Mijenfjorden Group of the Central Tertiary Basin. The strata have previously been assigned to the Lower
Cretaceous, but this assignment has been consequently rejected by this study.

- The c. $250 \mathrm{~m}$-thick succession is incorporated into the West Spitsbergen Fold-and-Thrust Belt and represents the fourth known structural outlier of the Van Mijenfjorden Group. The lower boundary directly overlies the Lower Cretaceous Helvetiafjellet Formation showing no evidence of tectonic deformation and is therefore argued to be a sedimentary contact.

- Comparison and correlation to a regional extensive and age-equivalent tephra layer in the lower Firkanten Formation show a synchronous early Selandian paralic facies belt extending for $100 \mathrm{~km}$ in a north-south direction from the Svea area via Longyearbyen to Sylfjellet. The actual extent of the Paleocene depositional basin must have exceeded the preserved extent of the Central Tertiary Basin by far.

- The investigated coal seams in the Firkanten Formation at Sylfjellet show both an in-seam random vitrinite reflectance $\left(R_{\mathrm{r}}\right)$ gradient, probably due to $R_{\mathrm{r}}$ suppression caused by bitumen impregnation as described by Marshall et al. [53]. $R_{\mathrm{r}}$ of the Firkanten Formation reflecting the thermal maturity on Sylfjellet is 0.62 $0.67 \%$, which is comparable to age-equivalent coals from Longyearben.

- Coalification reflecting at least $2 \mathrm{~km}$ of burial predates folding and thrusting at Sylfjellet.

Acknowledgements This research was partly funded by ARCEx partners and the Research Council of Norway (Grant number 228107). We are grateful to the German Federal Institute for Geosciences and Natural Resources/Karsten Piepjohn for funding and organizing the CASE 17 expedition, especially Lutz Reinhardt, Philipp Weniger, Andreas Lückge and guide Micha for support in the field in 2015. SAG, MEJ and IM appreciate the financial support from the Lower Cretaceous Basin Studies in the Arctic (LoCrA) consortium for their fieldwork at Sylfjellet. We are very grateful to Maximilian Weber for assistance during fieldwork in 2017 and to the UNIS logistics team for great support. Robert Spielhagen is acknowledged for information about his field campaign on Sylfjellet in the 1980s. We are thankful to Snorre Olaussen and William Helland-Hansen for critical and valuable comments on an earlier version of the manuscript. We sincerely appreciate the constructive and critical comments from Alvar Braathen and the efficient editorial handling by the Editor-in-Chief Henning Bauch.

Author contributions SAG, MEJ and IM first visited the locality and contributed with sedimentological and stratigraphic logging and description of the Lower Cretaceous succession. TH and MMJ undertook the fieldwork and sample collection in the Cretaceous and Paleogene succession. LEA prepared and analyzed zircons for $\mathrm{U}-\mathrm{Pb}$ dating. OL performed palynology analysis. GB and MMJ prepared the coal and measured vitrinite reflectance. MD and MMJ assigned the paleobotanic macrofossils. HRH identified the foraminifera. MMJ coordinated the study. All authors contributed to the writing of the manuscript. 


\section{Compliance with ethical standards}

Conflict of interest The authors declare that they have no conflict of interest.

Open Access This article is distributed under the terms of the Creative Commons Attribution 4.0 International License (http://creativeco mmons.org/licenses/by/4.0/), which permits unrestricted use, distribution, and reproduction in any medium, provided you give appropriate credit to the original author(s) and the source, provide a link to the Creative Commons license, and indicate if changes were made.

\section{References}

1. CASE Team (2001) The evolution of the West Spitsbergen Foldand-Thrust belt. In: Tessensohn F (ed) Intra-continental fold belts. Case 1: West Spitsbergen. Geologisches Jahrbuch Reihe B, Polar Issue 7. Federal Institute for Geosciences and Natural Resources, Hannover, pp 733-773

2. Nathorst AG (1888) Über die Schichtfolge und den Bau von Spitzbergen. In: Suess E (ed) Das Antlitz der Erde, vol 2. F. Tempsky, Wien, $\mathrm{p} 704$ (in German)

3. Bergh S, Ohta Y, Andresen A, Maher HD, Braathen A, Dallmann WK (1993) Geological map of Svalbard 1:100,000, sheet B8G St. Jonsfjorden, preliminary edition, black-and-white. Norsk Polarinstitutt, Troms $\emptyset$

4. Dallmann WK (2015) Geoscience Atlas of Svalbard, vol 148. Norwegian Polar Institute Report Series, Norwegian Polar Institute, Troms $\varnothing$

5. Dallmann WK, Andresen A, Bergh SG, Maher jr HD, Ohta Y (1993) Tertiary fold-and-thrust belt of Spitsbergen, Svalbard. meddelelser nr. 128. Norsk Polarinstitutt, Oslo

6. Dallmann W (2014) Geological map of Svalbard (1:750000) [Data set]. Norwegian Polar Institute. https://doi.org/10.21334/npola r.2014.09dbe7b2. Accessed Nov 2019

7. Harland WB, Anderson LM, Manasrah D, Butterfield NJ (1997) The Geology of Svalbard, vol 17. Geological Society, London

8. Flood B, Nagy J, Winsnes TS (1971) Geological Map Svalbard 1: 500,000, sheet 1G, Spitsbergen Southern Part. Norsk Polarinstitutt Skrifter, vol 154 A. Norsk Polarinstitutt, Oslo, Norway

9. Dallmann WK, Birkenmajer K, Dypvik H, Gjelberg JG, Keilen HB, Mork A, Nagy J, Nottvedt A, Pcelina TM, Steel RJ, Worsley D, Svalbard ISKF (1999) Lithostratigraphic lexicon of Svalbard. Review and recommendations for nomenclature use. Upper Palaeozoic to Quaternary bedrock. Norsk Polarinstitut, Oslo

10. Bergh S, Ohta Y, Andresen A, Maher H, Braathen A, Dallmann W (2003) Geological Map of Svalbard, 1: 100000 Sheet B8G St Jonsfjorden. Norsk Polarinstitutt Temakart, Tromso

11. Piepjohn K, von Gosen W (2001) The southern margin of the belt of emergent thrusting on the north coast of Isfjorden. In: Tessensohn F (ed) Intra-continental fold belts. CASE 1: West Spitsbergen. Geologisches Jahrbuch Reihe B, Polar Issue 7. Federal Institute for Geosciences and Natural Resources, Hannover, pp 129-160

12. Kellogg HE (1975) Tertiary stratigraphy and tectonism in Svalbard and continental drift. AAPG Bull 59(3):465-485

13. Braathen A, Bergh S, Karlsen F, Maher H, Andresen A, Hansen A-I, Bergvik A (1999) Kinematics of the Isfjorden-Ymerbukta Fault Zone: a dextral oblique-thrust ramp in the Tertiary foldthrust belt of Spitsbergen. Nor Geol Tidsskr 79(4):227-240
14. Livšic JJ (1974) Palaeogene deposits and the platform structure of Svalbard. Norsk Polarinstitutt Skrifter, vol 159. Norsk Polarinstitutt, Oslo

15. Haremo P, Andresen A, Dypvik H, Nagy J, Elverhøi A, Eikeland TA, Johansen H (1990) Structural development along the Billefjorden Fault Zone in the area between Kjellströmdalen and Adventdalen/Sassendalen, central Spitsbergen. Polar Res 8(2):195-216

16. Lyberis N, Manby G (1993) The origin of the West Spitsbergen Fold Belt from geological constraints and plate kinematics: implications for the Arctic. Tectonophysics 224(4):371-391. https:// doi.org/10.1016/0040-1951(93)90039-M

17. Lepvrier C (1994) The origin of the West Spitsbergen Fold belt from geological constraints and plate kinematics: implications for the Arctic-Comment. Tectonophysics 234(4):329-333. https:// doi.org/10.1016/0040-1951(94)90231-3

18. Maher HD, Braathen A, Bergh S, Dallmann W, Harland WB (1995) Tertiary or Cretaceous age for Spitsbergen's fold-thrust belt on the Barents Shelf. Tectonics 14(6):1321-1326

19. Maher HD, Bergh S, Braathen A, Ohta Y (1997) Svartfjella, Eidembukta, and Daudmannsodden lineament: tertiary orogenparallel motion in the crystalline hinterland of Spitsbergen's foldthrust belt. Tectonics 16(1):88-106. https://doi.org/10.1029/96tc0 2616

20. Saalmann K, Brommer A (1997) Stratigraphy and structural evolution of eastern Brøggerhalvøya, NW-Spitsbergen. Münstersche Forschung zur Geologie und Paläontologie 82:147-164

21. Saalmann K, Thiedig F (2002) Thrust tectonics on Brøggerhalvøya and their relationship to the Tertiary West Spitsbergen Fold-and-Thrust Belt. Geol Mag 139(1):47-72

22. Bruhn R, Steel R (2003) High-resolution sequence stratigraphy of a clastic foredeep succession (Paleocene, Spitsbergen): an example of peripheral-bulge-controlled depositional architecture. J Sediment Res 73(5):745-755

23. Jones MT, Augland LE, Shephard GE, Burgess SD, Eliassen GT, Jochmann MM, Friis B, Jerram DA, Planke S, Svensen HH (2017) Constraining shifts in North Atlantic plate motions during the Palaeocene by U-Pb dating of Svalbard tephra layers. Sci Rep $7: 6822$

24. Kleinspehn KL, Teyssier C (2016) Oblique rifting and the Late Eocene-Oligocene demise of Laurasia with inception of Molloy Ridge: deformation of Forlandsundet Basin, Svalbard. Tectonophysics 693:363-377

25. Piepjohn K, von Gosen W, Tessensohn F (2016) The Eurekan deformation in the Arctic: an outline. J Geol Soc 173(6):1007-1024

26. Bergh SG, Braathen A, Andresen A (1997) Interaction of basement-involved and thin-skinned tectonism in the Tertiary fold-thrust belt of central Spitsbergen, Svalbard. AAPG Bull 81(4):637-661

27. Steel RJ, Dalland A, Kalgraff K, Larsen V (1981) The Central Tertiary Basin of Spitsbergen: sedimentary development of a sheared-margin basin. Can Soc Pet Geol Mem 7:647-664

28. Müller RD, Spielhagen RF (1990) Evolution of the Central Tertiary Basin of Spitsbergen: towards a synthesis of sediment and plate tectonic history. Palaeogeogr Palaeoclimatol Palaeoecol 80(2):153-172

29. Blinova M, Faleide JI, Gabrielsen RH, Mjelde R (2013) Analysis of structural trends of sub-sea-floor strata in the Isfjorden area of the West Spitsbergen Fold-and-Thrust Belt based on multichannel seismic data. J Geol Soc 170(4):657-668

30. Harland WB, Horsfield WT (1974) West Spitsbergen Orogen. Geol Soc Lond Spec Publ 4(1):747-755. https://doi.org/10.1144/ gsl.sp.2005.004.01.46 
31. Ohta Y, Hjelle A, Andresen A, Dallmann W, Salvigsen O (1992) Geological map of Svalbard, scale 1: 100,000, sheet B9G 1sfjorden, Temakart 16. Norsk Polarinstitutt, Oslo

32. Orvin AK (1940) Outline of the geological history of Spitsbergen. Skrifter om Svalbard og Ishavet, vol 78. Norges Svalbard-og Ishavsunders $\varnothing$ kelser, Oslo

33. Birkenmajer K (1972) Tertiary history of Spitsbergen and continental drift. Acta Geol Pol 22(2):193-218

34. Bergh SG, Grogan P (2003) Tertiary structure of the SørkappHornsund region, south Spitsbergen, and implications for the offshore southern extension of the fold-thrust belt. Nor Geol Tidsskr 83(1):43-60

35. von Gosen W, Paech H-J, Piepjohn K (2001) Involvement of Basal Tertiary Strata in the Fold-Belt Deformation in Nordenskiöld Land. In: Tessensohn F (ed) Intra-continental fold belts. CASE 1: West Spitsbergen. Geologisches Jahrbuch Reihe B, Polar Issue 7. Federal Institute for Geosciences and Natural Resources, Hannover, pp 229-246

36. Cepek P, Krutzsch W (2001) Conflicting interpretations of the Tertiary Biostratigraphy of Spitsbergen and New Palynological Results. In: Tessensohn F (ed) Intra-continental fold belts. CASE 1: West Spitsbergen. Geologisches Jahrbuch Reihe B, Polar Issue 7. Federal Institute for Geosciences and Natural Resources, Hannover, pp 551-602

37. Orvin AK (1934) Geology of the Kings Bay region, Spitsbergen, with special reference to the coal deposits. Skrifter om Svalbard og Ishavet, vol 57. Norges Svalbard-og Ishavsundersøkelser, Oslo

38. Dörr N, Lisker F, Clift PD, Carter A, Gee DG, Tebenkov AM, Spiegel C (2012) Late Mesozoic-Cenozoic exhumation history of northern Svalbard and its regional significance: constraints from apatite fission track analysis. Tectonophysics 514-517:81-92. https://doi.org/10.1016/j.tecto.2011.10.007

39. Nagy J (1970) Ammonite faunas and stratigraphy of Lower Cretaceous (Albian) rocks in southern Spitsbergen. Norsk Polarinstitutt Skrifter, vol 152. Norsk Polarinstitutt, Oslo, Norway

40. Dörr N, Lisker F, Piepjohn K, Spiegel C (2019) Cenozoic development of northern Svalbard based on thermochronological data. Terra Nova. https://doi.org/10.1111/ter.12402

41. Dörr N, Lisker F, Jochmann MM, Rainer T, Schlegel A, Schubert K, Spiegel C (2018) Subsidence, rapid inversion, and slow erosion of the Central Tertiary Basin of Svalbard: evidence from the thermal evolution and basin modeling. Circum-Arctic Structural Events: Tectonic Evolution of the Arctic Margins and Trans-Arctic Links with Adjacent Orogens. https://doi. org/10.1130/2018.2541(09)

42. Petersen TG, Thomsen TB, Olaussen S, Stemmerik L (2016) Provenance shifts in an evolving Eurekan foreland basin: the Tertiary Central Basin. J Geol Soc, Spitsbergen. https://doi.org/10.1144/ jgs2015-076

43. Elling FJ, Spiegel C, Estrada S, Davis DW, Reinhardt L, HenjesKunst F, Allroggen N, Dohrmann R, Piepjohn K, Lisker F (2016) Origin of Bentonites and Detrital Zircons of the Paleocene Basilika Formation. Svalbard. Frontiers in Earth Science 4:73

44. Charles AJ, Condon DJ, Harding IC, Pälike H, Marshall JEA, Cui Y, Kump L, Croudace IW (2011) Constraints on the numerical age of the Paleocene-Eocene boundary. Geochem Geophys Geosyst. https://doi.org/10.1029/2010GC003426

45. Helland-Hansen W (1990) Sedimentation in Paleogene Foreland Basin, Spitsbergen (1). AAPG Bulletin 74(3):260-272

46. Bergh SG, Maher HD, Braathen A (2000) Tertiary divergent thrust directions from partitioned transpression, Brøggerhalv ya. Spitsbergen. Norsk Geologisk Tidsskrift 80(2):63-81

47. Braathen A, Bergh SG, Maher HD (1999) Application of a critical wedge taper model to the Tertiary transpressional fold-thrust belt on Spitsbergen. Svalbard. Geological Society of America Bulletin 111(10):1468-1485

48. Leever KA, Gabrielsen RH, Faleide JI, Braathen A (2011) A transpressional origin for the West Spitsbergen fold-and-thrust belt: Insight from analog modeling. Tectonics. https://doi. org/10.1029/2010TC002753

49. Manum SB, Throndsen T (1986) Age of Tertiary formations on Spitsbergen. Polar Res 4(2):103-131

50. Paech H-J, Koch J (2001) Coalification in post-Caledonian sediments on Spitsbergen. Intra-continental fold belts. CASE 1: West Spitsbergen. Polar Issue 7. Federal Institute for Geosciences and Natural Resources, Hannover, pp 507-534

51. Manum SB, Throndsen T (1978) Rank of coal and dispersed organic matter and its geological bearing in the Spitsbergen Tertiary. Norsk Polarinstitutt Årbok 1977:159-177

52. Throndsen T (1982) Vitrinite reflectance studies of coal and dispersed organic matter in Tertiary deposits in the Adventdalen area. Svalbard. Polar Research 1982(2):77-91. https://doi. org/10.1111/j.1751-8369.1982.tb00478.x

53. Marshall C, Uguna J, Large DJ, Meredith W, Jochmann M, Friis B, Vane C, Spiro BF, Snape CE, Orheim A (2015) Geochemistry and petrology of palaeocene coals from Spitzbergen - Part 2: maturity variations and implications for local and regional burial models. Int J Coal Geol 143:1-10. https://doi.org/10.1016/j. coal.2015.03.013

54. Jochmann M, Brugmans P, Often M, Friis B, Bernt H (2015) Coal resources on Spitsbergen-status, geology and challenges. In: Abstracts and proceedings of the geological society of Norway, 31th geological winter meeting, Stavanger, Norway, 2015

55. Steel R, Gjelberg J, Helland-Hansen W, Kleinspehn K, Nøttvedt A, Rye-Larsen M (1985) The Tertiary strike-slip basins and orogenic belt of Spitsbergen. In: The Society of Economic Paleontologists and Minaralogists (SEPM) 37

56. Nagy J (2005) Delta-influenced foraminiferal facies and sequence stratigraphy of Paleocene deposits in Spitsbergen. Palaeogeogr Palaeoclimatol Palaeoecol 222(1-2):161-179. https://doi. org/10.1016/j.palaeo.2005.03.014

57. Lüthje CJ (2008) Transgressive development of coal-bearing coastal plain to shallow marine setting in a flexural compressional basin, Paleocene, Svalbard, Arctic Norway. PhD thesis. Department of Earth Science, University of Bergen, Bergen, Norway

58. Mattinson JM (2005) Zircon U-Pb chemical abrasion ("CATIMS") method: combined annealing and multi-step partial dissolution analysis for improved precision and accuracy of zircon ages. Chem Geol 220(1):47-66

59. Huyskens MH, Zink S, Amelin Y (2016) Evaluation of temperature-time conditions for the chemical abrasion treatment of single zircons for U-Pb geochronology. Chem Geol 438:25-35

60. Svensen HH, Hammer $\varnothing$, Corfu F (2015) Astronomically forced cyclicity in the Upper Ordovician and U-Pb ages of interlayered tephra, Oslo Region, Norway. Palaeogeogr Palaeoclimatol Palaeoecol 418:150-159

61. Krogh T (1973) A low-contamination method for hydrothermal decomposition of zircon and extraction of $\mathrm{U}$ and $\mathrm{Pb}$ for isotopic age determinations. Geochim Cosmochim Acta 37(3):485-494

62. Augland LAA, Corfu F (2010) Age, structural setting, and exhumation of the Liverpool Land eclogite terrane. East Greenland Caledonides. Lithosphere 2(4):267-286. https://doi.org/10.1130/ L75.1

63. Bowring JF, McLean NM, Bowring SA (2011) Engineering cyber infrastructure for U-Pb geochronology: Tripoli and U-Pb_Redux. Geochem Geophys Geosyst. https://doi.org/10.1029/2010GC0034 79

64. Schmitz MD, Schoene B (2007) Derivation of isotope ratios, errors, and error correlations for U-Pb geochronology using ${ }^{205} \mathrm{~Pb}-{ }^{235} \mathrm{U}-\left({ }^{233} \mathrm{U}\right)$-spiked isotope dilution thermal ionization 
mass spectrometric data. Geochem Geophys Geosyst. https://doi. org/10.1029/2006GC001492

65. Ludwig K (2003) ISOPLOT/Ex, A geochronological toolkit for Microsoft Excel. Berkeley Geochronology Center Special Publication $4: 70$

66. Jaffey A, Flynn K, Glendenin L, Bentley W, Essling A (1971) Precision measurement of half-lives and specific activities of $U$ 235 and U 238. Phys Rev C 4(5): 1889

67. Kaiser ML, Ashraf R (1974) Gewinnung und Präparation fossiler Pollen und Sporen sowie anderer Palynomorphae unter besonderer Berücksichtigung der Siebmethode. Geologisches Jahrbuch Reihe A 25:85-114

68. Nagy J, Løfaldli M, Bäckström S (1988) Aspects of foraminiferal distribution and depositional conditions in Middle Jurassic to Early Cretaceous shales in eastern Spitsbergen. Abhandlungen der Geologischen Bundesanstalt, Wien 30:297-300

69. International Organization for Standardization (ISO) (1985) ISO 7404-2:1985. Methods for the petrographic analysis of bituminous coal and anthracite-Part 2: Preparation of coal samples, International Organization for Standardization, Geneva, Switzerland, 8 $\mathrm{pp}$

70. International Organization for Standardization (ISO) (1994) ISO 7404-5: 1994. Methods for the petrographic analysis of bituminous coal and anthracite-Part 5: Method of determining microscopically the reflectance of vitrinite, International Organization for Standardization, Geneva, Switzerland, $12 \mathrm{pp}$

71. Corfu F, Polteau S, Planke S, Faleide JI, Svensen H, Zayoncheck A, Stolbov N (2013) U-Pb geochronology of Cretaceous magmatism on Svalbard and Franz Josef Land, Barents Sea large igneous province. Geol Mag 150(6):1127-1135

72. Midtkandal I, Svensen HH, Planke S, Corfu F, Polteau S, Torsvik TH, Faleide JI, Grundvåg S-A, Selnes H, Kürschner W, Olaussen S (2016) The Aptian (Early Cretaceous) oceanic anoxic event (OAE1a) in Svalbard, Barents Sea, and the absolute age of the Barremian-Aptian boundary. Palaeogeogr Palaeoclimatol Palaeoecol 463(Supplement C):126-135. https://doi.org/10.1016/j.palae o.2016.09.023

73. Vickers ML, Price GD, Jerrett RM, Watkinson M (2016) Stratigraphic and geochemical expression of Barremian-Aptian global climate change in Arctic Svalbard. Geosphere 12(5):1594-1605. https://doi.org/10.1130/ges01344.1

74. Grundvåg S-A, Jelby ME, Śliwińska KK, Nøhr-Hansen H, Aadland T, Sandvik SE, Tennvassås I, Engen T, Olaussen S (2019) Sedimentology and palynology of the Lower Cretaceous succession of central Spitsbergen: integration of subsurface and outcrop data. Norweg J Geol 99:32. https://doi.org/10.17850/njg006

75. Grundvåg SA, Marin D, Kairanov B, Śliwińska KK, Nøhr-Hansen H, Jelby ME, Escalona A, Olaussen S (2017) The Lower Cretaceous succession of the northwestern Barents Shelf: onshore and offshore correlations. Mar Pet Geol 86(Supplement C):834-857. https://doi.org/10.1016/j.marpetgeo.2017.06.036

76. Thiele-Pfeifer H (1988) Die Mikroflora aus dem mitteleozänen Ölschiefer von Messel bei Darmstadt [The microflora from the Middle Eocene oil shale of Messel near Darmstadt]. Palaeontographica Abt B Band 211 Lieferung 1-3:1-86

77. Manum SB (1962) Studies in the Tertiary flora of Spitsbergen, with notes on Tertiary floras of Ellesmere Island, Greenland, and Iceland: a palynological investigation. Norsk Polarinstitutt Skrifter, vol 125. Norsk Polarinstitutt, Oslo, Norway

78. Krutzsch W (2001) An upper cretaceous microflora from Spitsbergen. In: Tessensohn F (ed) Intra-continental fold belts. CASE 1: West Spitsbergen. Geologisches Jahrbuch Reihe B, Polar Issue 7. Federal Institute for Geosciences and Natural Resources, Hannover, pp 693-718
79. Heer O (1855) Flora Tertiaria Helvetiae. Die tertiäre Flora der Schweiz, vol 1. Verlag der Lithographischen Anstalt von J. Wurster \& Compagnie, Winterthur

80. Penhallow DP (1908) Report on Tertiary plants of British Columbia collected by Lawrence M. Lambe in 1906 together with a discussion of previously recorded Tertiary floras, vol 1013. Canada Department of Mines, Geological Survey Branch

81. Chaney RW (1950) A revision of fossil Sequoia and Taxodium in western North America based on the recent discovery of Metasequoia. Trans Am Philos Soc 40(3):171-263

82. Uguna JO, Carr AD, Marshall C, Large DJ, Meredith W, Jochmann M, Snape CE, Vane CH, Jensen MA, Olaussen S (2017) Improving spatial predictability of petroleum resources within the Central Tertiary Basin, Spitsbergen: a geochemical and petrographic study of coals from the eastern and western coalfields. Int J Coal Geol 179:278-294

83. Atkinson DJ (1963) Tertiary rocks of Spitsbergen. AAPG Bull 47(2):302-323

84. Parker JR (1967) The Jurassic and Cretaceous sequence in Spitsbergen. Geol Mag 104(5):487-505. https://doi.org/10.1017/S0016 756800049220

85. Jones MT, Eliassen GT, Shephard GE, Svensen HH, Jochmann M, Friis B, Augland LE, Jerram DA, Planke S (2016) Provenance of bentonite layers in the Palaeocene strata of the Central Basin, Svalbard: implications for magmatism and rifting events around the onset of the North Atlantic Igneous Province. J Volcanol Geotherm Res 327:571-584

86. Jochmann MM (2004) The geology of the Ispallen area, Svalbard, with emphasis on the coal bearing Firkanten Formation. Unpublished diploma thesis, University Centre in Svalbard, LMU München, NTNU Trondheim

87. Marshall CJ (2013) Palaeogeographic development and economic potential of the coal-bearing palaeocene Todalen Member, Spitsbergen. PhD thesis, University of Nottingham, The University Centre in Svalbard

88. Dallmann WK, Kjærnet T, Nøttvedt A (2001) Descriptions to the Geological map of Svalbard 1: 100,000, sheet C9G Adventdalen. Norsk Polarinstitutt Troms $\varnothing$, Norway

89. Schaupeter W, Struck U (1988) Flächenhafte Kartierung der mesozoischen und känozoischen Sedimente auf Bohemannflya und Erdmannflya am nördlichen Isfjordenufer, Spitsbergen; Svalbard. Unpublished diploma thesis part A Christian-Albrechts-Universität, Kiel, Germany

90. Smelror M, Larssen GB (2016) Are there Upper Cretaceous sedimentary rocks preserved on Sørkapp Land, Svalbard? Norw J Geol 96:1-12

91. Hurum JH, Roberts AJ, Dyke GJ, Grundvåg S-A, Nakrem HA, Midtkandal I, Śliwinska KK, Olaussen S (2016) Bird or maniraptoran dinosaur? A femur from the Albian strata of Spitsbergen, Arctic Norway. Acta Palaeontol Polon 67:137-147

92. Challinor A (1967) The structure of Brøggerhalvøya, Spitsbergen. Geol Mag 104(04):322-336

93. Uguna JO (2015) Maturity, oil source rock and retorting potential of perhydrous coals in the Central Tertiary Basin, Spitsbergen. $\mathrm{PhD}$-thesis, Univertity of Nottingham

94. Norwegian Polar Institute (2016) Geological map of Svalbard (1:250000) [Data set]. Norwegian Polar Institute, Troms $\varnothing$. https ://doi.org/10.21334/npolar.2016.616f7504

95. Norwegian Polar Institute (2014) Kartdata Svalbard 1:100 000 (S100 Kartdata) [Dataset]. Norwegian Polar Institute/USGS Landsat, Troms $\varnothing$

96. Jakobsson M, Mayer L, Coakley B, Dowdeswell JA, Forbes S, Fridman B, Hodnesdal H, Noormets R, Pedersen R, Rebesco M, Schenke HW, Zarayskaya Y, Accettella D, Armstrong A, 
Anderson RM, Bienhoff P, Camerlenghi A, Church I, Edwards M, Gardner JV, Hall JK, Hell B, Hestvik O, Kristoffersen Y, Marcussen C, Mohammad R, Mosher D, Nghiem SV, Pedrosa MT, Travaglini PG, Weatherall P (2012) The International Bathymetric Chart of the Arctic Ocean (IBCAO) Version 3.0. Geophys Res Lett. https://doi.org/10.1029/2012g1052219

97. Midbøe P (1985) Kongsfjordfeltet (Paleocen) Spitsbergen, Sedimentologisk og tektonisk utvikling. Unpublished Cand. Mag. thesis, University of Bergen, Geological Institute, Bergen, Norway
98. Norwegian Polar Institute (2014) Terrengmodell Svalbard (S0 Terrengmodell) [Dataset]. Norwegian Polar Institutt, Troms $\varnothing$

99. Cohen KM, Finney SC, Gibbard PL, Fan J-X (2013) The ICS international chronostratigraphic chart. Episodes 36(3):199-204

Publisher's Note Springer Nature remains neutral with regard to jurisdictional claims in published maps and institutional affiliations. 